University of South Florida

DIGITAL COMMONS

Digital Commons @ University of

@ UNIVERSITY OF SOUTH FLORIDA

South Florida

The Inside, Outside, and Upside Downs of

Children's Literature: From Poets and Pop-ups

to Princesses and Porridge

Teaching and Learning

$1-1-2016$

\title{
Chapter 05: The Right Book for the Right Reader at the Right Time
}

Jenifer Jasinski Schneider

University of South Florida, jschneid@usf.edu

Follow this and additional works at: https://digitalcommons.usf.edu/childrens_lit_textbook

Part of the Education Commons

\section{Recommended Citation}

Schneider, Jenifer Jasinski, (2016). The Right Book for the Right Reader at the Right Time. In The Inside, Outside, and Upside Downs of Children's Literature: From Poets and Pop-ups to Princesses and Porridge (p. 98-158). http://dx.doi.org/10.5038/9780977674411.ch5

This Book Chapter is brought to you for free and open access by the Teaching and Learning at Digital Commons @ University of South Florida. It has been accepted for inclusion in The Inside, Outside, and Upside Downs of Children's Literature: From Poets and Pop-ups to Princesses and Porridge by an authorized administrator of Digital Commons@ @niversity of South Florida. For more information, please contact digitalcommons@usf.edu. 


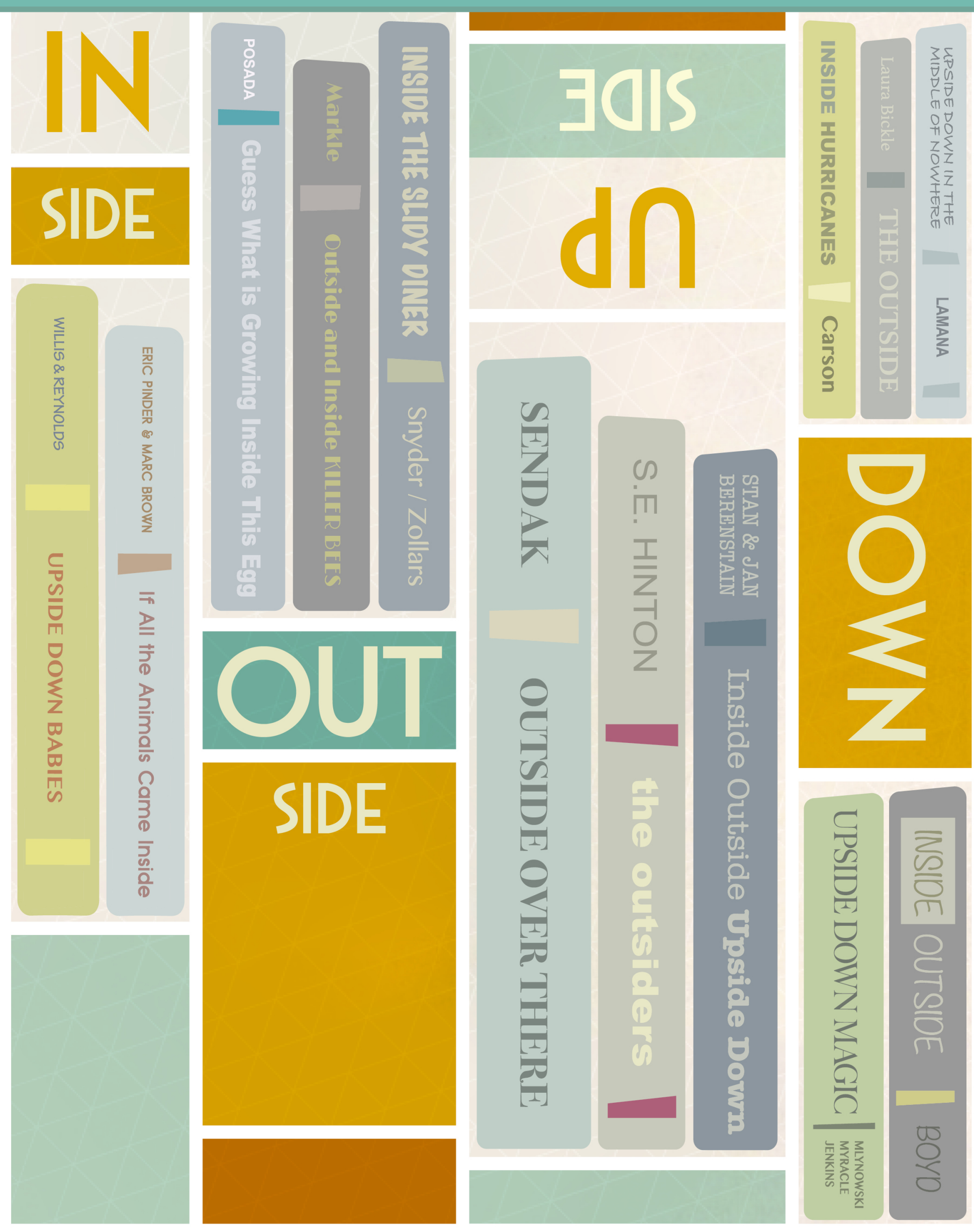

\section{THE INSIDE, OUTSIDE, AND UPSIDE DOWIS From Poets and Pop-ups to OF CHILDREN'S LITERATURE Princesses and Porridge}




\section{The Inside, Outside, and Upside Downs of Children's Literature: From Poets and Pop-ups to Princesses and Porridge}

Jenifer Jasinski Schneider, Ph.D. 
Copyright

Published by The University of South Florida Library, 4202 E. Fowler Avenue, Tampa, FL 33620.

Copyright (C2016 by Jenifer Jasinski Schneider. All rights reserved.

\section{(c) $(1) \odot$}

This work is licensed under a Creative Commons Attribution-NonCommercial-NoDerivatives 4.0 International License.

Author and Editor in Chief: Jenifer Jasinski Schneider

Editorial Director: Monica Metz-Wiseman

Media Project Manager and Producer: Christine Brown

Video Producers and Editors: Jared Brown, Jason Su, Ian Crenshaw, Jessica Brennen,

Diana Trueman, Jeremy Willis

Art Director: Stephanie Rivera

Illustrators and Multimedia Designers: William Tillis and Elise Michal

Copyright Coordinator: LeEtta M. Schmidt

Open-Access Editor: Jason Boczar

Editorial Manager: Carol Ann Borchert

Editorial Project Manager: Chelsea Johnston

Cover image book credits:

Upside Down Babies by Jeanne Willis and Adrian Reynolds (C)2013 Andersen Press; If All the Animals

Came Inside by Eric Pinder and Marc Tolon Brown (C)2012 Little, Brown and Company; Guess What Is Growing Inside This Egg by Mia Posada (C2007 Millbrook Press; Outside and Inside Killer Bees by Sandra Markle (C)2004 Walker \& Co.; Inside the Slidy Diner by Laurel Snyder and Jaime Zollars (C)2008 Tricycle Press; Outside Over There by Maurice Sendak (C)1989 HarperCollins; The Outsiders by S.E. Hinton, original cover art by Robert Hunt (C1967 Viking Press. Mass Market edition (C1997 Speak; Inside Outside Upside Down by Stan and Jan Berenstain (C1968 Random House; Upside Down Magic by Sarah Mlynowski, Lauren Myracle, and Emily Jenkins (C)2015 Scholastic Press; Inside Outside by Lizi Boyd (C)2013 Chronicle Books; Inside Hurricanes by Mary Kay Carson (C)2010 Sterling; The Outside by Lauren Bickle (C)2013 Houghton Mifflin Harcourt; Upside Down in the Middle of Nowhere by Julie T.

Lamana (C)2014 Chronicle Books.

Library of Congress Cataloging-in-Publication Data

Schneider, Jenifer Jasinski, 1968-

The Inside, Outside, and Upside Downs of Children's Literature: From Poets and Pop-ups to Princesses and Porridge / Jenifer Jasinski Schneider.

ISBN- 978-0-9776744-1-1 eBook

ISBN- 978-0-9776744-2-8 print

The Internet addresses listed in the text were accurate at the time of publication. 


\section{HOTTOPICSANDCURIOUSQUANDARIES}

SECTION2 


\section{CHAPTER \\ THE RIGHT BOOK FOR THE RIGHT \\ 05 READER AT THE RIGHT TIME \\ [LITERARY ANALYSIS, QUALITY, AND DEVELOPMENTAL PERSPECTIVES]}

Although there is deep literary value in children's literature resulting in critical acclaim as well as commercial success, each year, authors, illustrators, and publishers also produce a lot of duds. When selecting books, you can rely on the awards to determine literary value, but as previously discussed, the "best" books may not interest children, young adults, or you. In order to select books and determine the right book for the right reader at the right time (including yourself), let's review criteria for evaluating books and then connect those criteria to how and what readers read.

\section{Determining Quality}

Considering that, "rhetorical tradition has too often distorted issues of intention and purpose by setting up unnatural distinctions" (DiPardo, 1990, p. 66), I hesitate to dwell on brief and narrow descriptions of categories for literary analysis. However, I want you to understand how good books work, and just like a car mechanic, we have to go under the hood, identify the parts, determine if they function successfully, and put everything back together. Therefore, we can determine quality through the following process:

(1) identifying the author's purpose,

(2) selecting and applying the appropriate criteria to evaluate books,

(3) matching books to readers, and then

(4) judging the overall product in connection with the intended audience.

I know absolutely nothing about cars. It's just a simple and common analogy. I promise there won't be any talk of overhead cams and drive shafts-or windshield wipers.

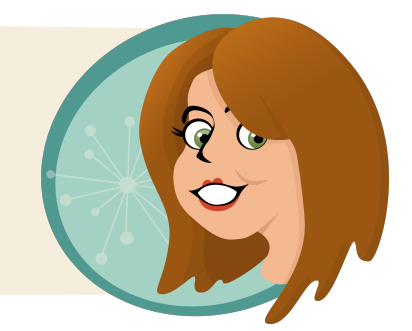




\section{Question \#1: What is the author's and/or illustrator's purpose?}

\section{Literary Purpose and Text Structures: A Vehicle for Communication}

In books, linguistic features are embedded in text structures and they combine to form various modes of discourse. The modes of discourse in children's literature are the same modes in adult literature. According to Bain (1866, as cited in DiPardo, 1990), literary modes include narration, exposition, description, and argument.

Think about literary purpose in connection to the phrase, "form follows function." The text will take a different shape depending on its purpose-just like different types of vehicles are used for different purposes: Sedan, Pickup, Van, Convertible.

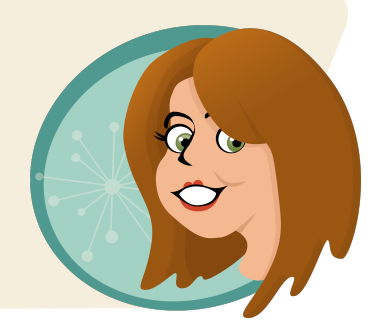

Narration (fiction). Narratives are a linguistic structuring of events in a manner similar to the actual or imagined sequence of lived events (Bowditch, 1976; Labov, 1972). Narratives include action and events multiplied into a series or, as Sternberg (2010) described it, "sequentiality-plus" (p. 546). Narratives tell a story, set in a particular place with characters and a plot. Another common term is "fiction" which refers to the notion that the story did not actually happen and the characters and events were "made up." Fictional stories could happen, but they haven't actually happened, such as the events in Pointe (Figure 5.1).

I wish I could say the day Donovan came home was extraordinary from the start, that I woke up knowing something special would happen that Thursday evening in October. But the truth is, it's like any other day of the week (Colbert, 2014, p. 1).

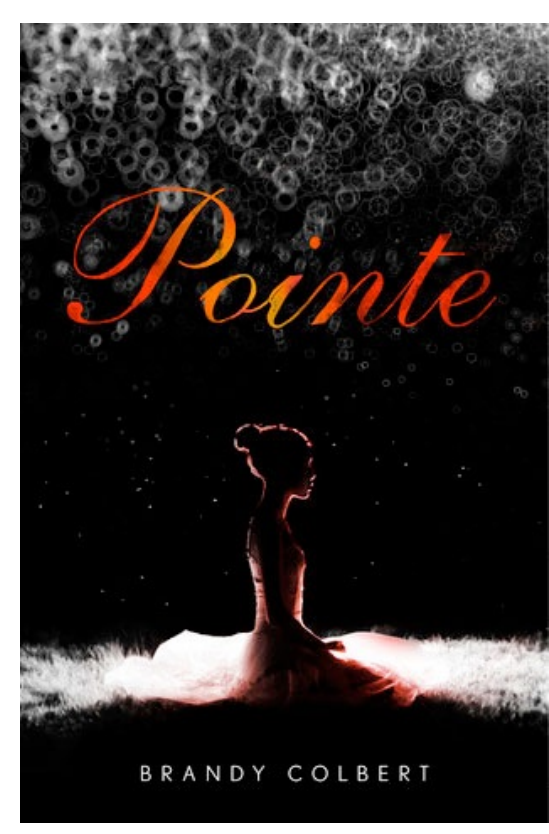

Figure 5.1

Fictional stories could happen, but they haven't actually happened. An example of a fictional story with an authentically flawed protagonist and realistic plot twists is Pointe by Brandy Colbert, 2014, New York, NY: G.P. Putnam's Sons Books for Young Readers. Copyright 2014 by Brandy Colbert. 
Or, in the case of fantasy, (Figure 5.2), the events could never happen (finding a fountain of youth), but the author forms a story around them.

There was something strange about the wood. If the look of the first house suggested that you'd better pass it by, so did the look of the wood, but for quite a different reason. The house was so proud of itself that you wanted to make a lot of noise as you passed, and maybe even throw a rock or two. But the wood had a sleeping, otherworld appearance that made you want to speak in whispers (From Tuck Everlasting by Natalie Babbitt, 1975, p. 6).

Or, in the case of fictionalized biography, the characters were real people and the life events were real, but the details of the events may be imagined or made up to illustrate the real and tell a better story (e.g., creating dialogue) (Figure 5.3).

On a continent of many songs, in a country shaped like the arm of a tall guitarrista, the rain drummed down on the town of Temuco.

Neftalí Reyes sat in his bed, propped up by pillows, and stared at the schoolwork in front of him. His teacher called it simple addition, but it was never simple for him. How he wished the numbers would disappear! He squeezed his eyes closed and then opened them.

The twos and threes lifted from the page and waved for the others to join them. The fives and sevens sprang upward, and finally, after much prodding, the fours, ones, and sixes came along. But the nines and zeros would not budge so the others left them. They held hands in a long procession of tiny figures, flew across the room and escaped through the window crack. Neftali closed the book and smiled (From The Dreamer by Pam Muñoz Ryan, 2010, p. 1-2).

The key determinant for fiction is the telling of a story (plot, setting, characters) of an actual or imagined sequence of lived events.

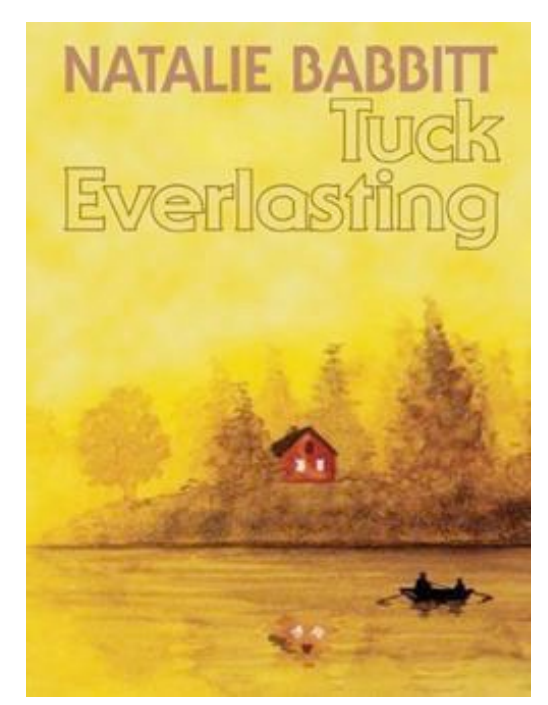

Figure 5.2

Tuck Everlasting is a story about living forever. Tuck Everlasting by Natalie Babbitt, 1975, New York, NY: Farrar, Straus and Giroux. Copyright 1975 by Natalie Babbitt.

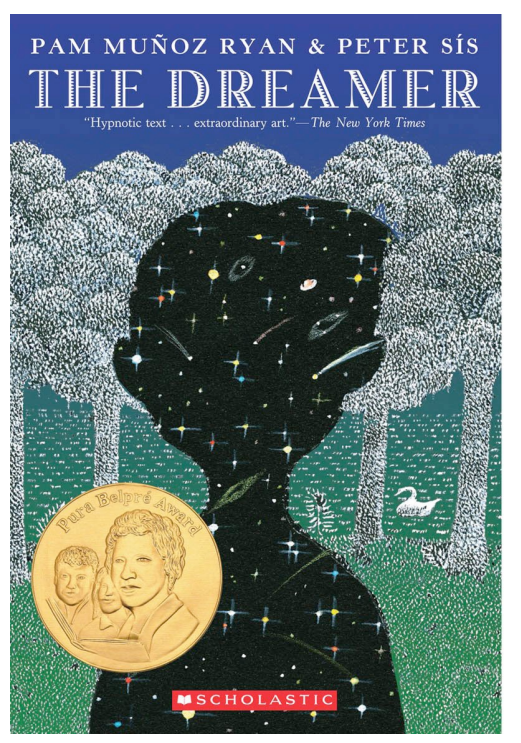

Figure 5.3

Fictionalized biographies are stories based on the true lives of real people. The story of Neftalí Reyes (also known as Pablo Neruda, the Nobel Prize-winning poet) is recreated by Pam Muñoz Ryan and illustrated by Peter Sís. The Dreamer by Pam Muñoz Ryan and illustrated by Peter Sís, 2010, New York, NY: Scholastic Press. Cover art copyright 2010 by Peter Sís. 
Information (nonfiction). In expository texts, the purpose is to explain. As such, expository text structures are used to present information or to describe phenomena (See Berman \& Katzenberger, 2004; Caswell \& Duke, 1998). More commonly called "information books" or "nonfiction," the authors and illustrators of these books explicate a topic (Figure 5.4). Informational books are defined as those written to present, organize, clarify, and interpret documentable, factual material (ALA, nd, Sibert Medal). The "presentation" of factual material can take many forms and this is where the writer's skill comes into play. For example, in the Family Romanov: Murder, Rebellion, and the Fall of Imperial Russia, Candace Fleming writes the story of one family, weaving together different chains of events while also using maps, charts, definitions, and primary source documents to substantiate her points and to contextualize the circumstances and resulting actions.

Listen to Text Messages Episode 79, A Conversation with Candace Fleming, 2014, as Candace discusses historical story telling and her research process.

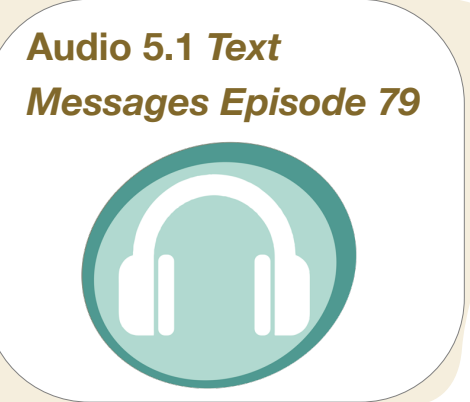

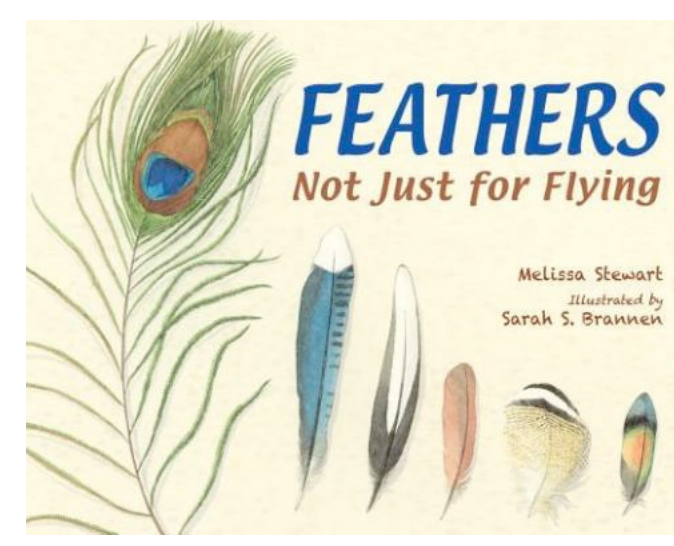

Figure 5.4

Nonfiction authors use expository text structures to present information. For example, Melissa Stewart used labels and short explanations to explore different types of feathers in Feathers Not Just for Flying by Melissa Stewart and illustrated by Sarah S. Brannen, 2014, Watertown, MA: Charlesbridge Publishing. Cover art copyright 2014 by Sarah S. Brannen.

Good nonfiction writers use engaging writing techniques to capture the audience's attention. For example, Vicki Cobb uses real life examples and directly asks readers to think through problems in her nonfiction text, I Face The Wind by Vicki Cobb and illustrated by Julia Gorton, 2003, New York, NY: HarperCollins Publishers.

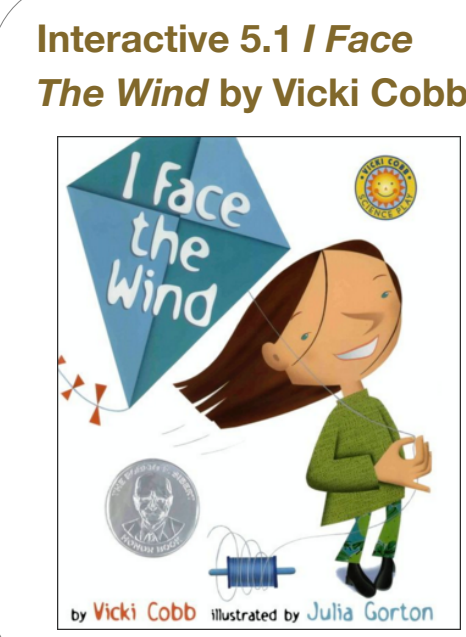

Description. Descriptive writing includes a main topic with related sub-topics that are explained clearly and in detail (Sanders \& Moudy, 2008). Similar to expository texts, descriptive texts may present information; however, descriptive writing offers more elaborative detail. For example, in Witches: The Absolutely True Tale of Disaster in Salem, Rosalyn Schanzer (2011) uses bold imagery and straightforward language to describe the Salem Witch trials (Figure 5.5).

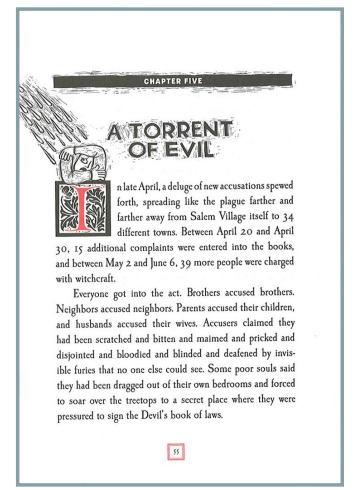

Figure 5.5

Rosalyn Schanzer uses honest prose and straightforward examples to describe numerous people, places, and events surrounding the Salem Witch Trials. Excerpt from Witches!: The Absolutely True Tale of Disaster in Salem, by Rosalyn Schanzer, 2011, Washington, DC: National Geographic Books. Copyright 2011 by Rosalyn Schanzer. 
Descriptive writing can be found in many fictional stories (Figure 5.6) such as Jane Yolen's Owl Moon. In contrast to Schanzer, Yolen creates quiet imagery by selecting delicate words that describe owling in the late night.

The writers of horror, myths, and legends rely on descriptive writing to build suspense, describe surroundings, and relate emotions. J.R.R. Tolkien's The Hobbit (1937, p.1), is filled with rich, descriptive language:

In a hole in the ground there lived a hobbit. Not a nasty, dirty, wet hole, filled with the ends of worms and an oozy smell, nor yet a dry, bare, sandy hole with nothing in it to sit down on or to eat: it was a hobbit hole, and that means comfort.

Descriptive writing is often used to present complex ideas or events. For example, Peter Sís (1998) wrote and illustrated Tibet based on his father's personal diary, which his father kept while he separated from the family to work in Tibet for two years (Figure 5.7).

Some poetry is also a form of descriptive writing. For example, Langston Hughes (1994) uses specific objects, repetition, and dialect to visually and spiritually portray the content and theme of his poem, Mother to Son (Figure 5.8). Descriptive writing provides elaboration and sensory detail.

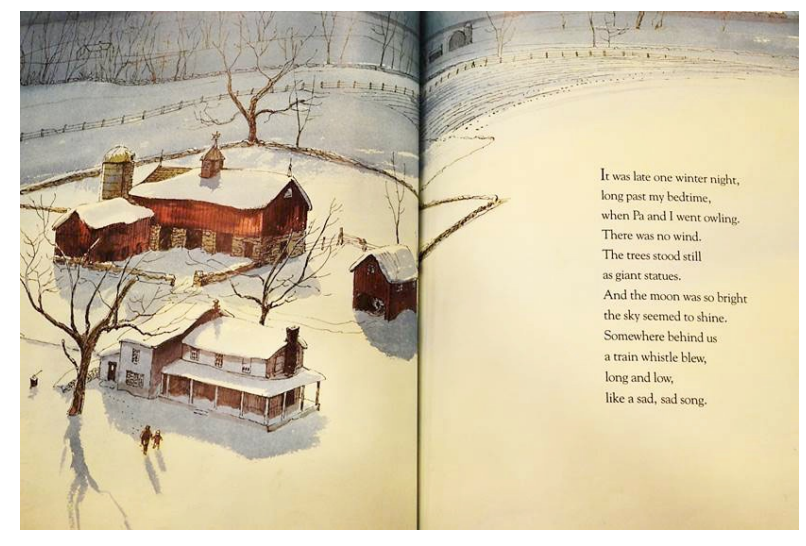

Figure 5.6

Jane Yolen's text for Owl Moon captures the main character's feelings as well as the quiet of the snow and the still of the late night. Excerpt from Owl Moon by Jane Yolen and illustrated by John Schoenherr, 1987, New York, NY: Philomel Books. Text copyright 1987 by Jane Yolen and illustration copyright 1987 by John Schoenherr.

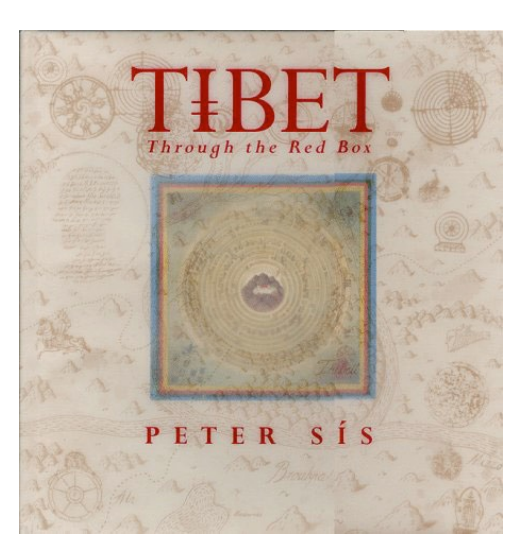

Figure 5.7

Peter Sís uses his father's diary as inspiration for Tibet Through the Red Box by Peter Sís, 1998, New York, NY: Farrar, Straus and Giroux. Copyright 1998 by Peter Sís.
Figure 5.8

Poetic language is often descriptive. For example, Langston Hughes uses sensory detail in his poem, Mother to Son, in The Dream Keeper and Other Poems by Langston Hughes and illustrated by Brian Pinkney, 1994, New York, NY: Alfred A. Knopf. Text copyright 1932/1960 by Langston Hughes and 1994 by the Estate of Langston Hughes, illustrations copyright 1994 by Brian Pinkney. 
Argumentation. Argument is not about "winning" a debate. Rather, a literary argument reflects the writer's ability to engage in mature reasoning and to think through issues in order to evaluate them (Crusius \& Channell, 2009; Knoblauch, 2011). In an argument, just like a position paper, the author uses different writing techniques, but with an evaluative perspective. Authors who present an argument may use descriptive or narrative techniques but they also use techniques specific to argument such as how they organize the text or address the reader's ethics, reason, and emotions (Lauer, et.al., 2000) (Figure 5.9). For example, in Separate is Never Equal: Sylvia Mendez and her Family's Fight for Desegregation, Duncan Tonatiuh writes about Sylvia's courtroom experience, sharing her emotional reactions to unethical behavior:

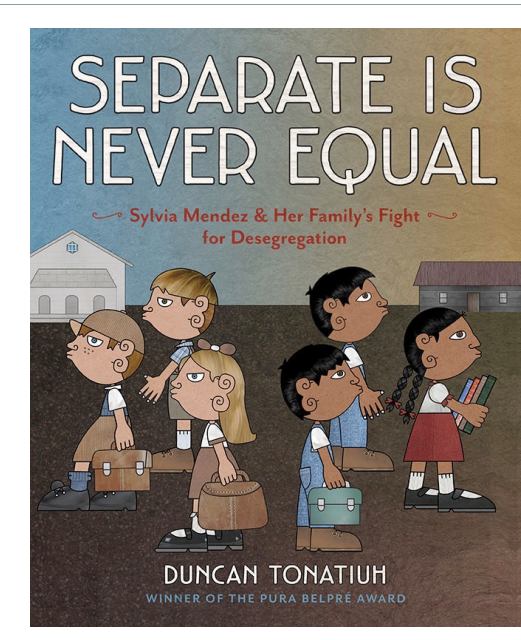

Figure 5.9

Duncan Tonatiuh tells the story of Sylvia Mendez using narrative techniques and argumentation. Separate is Never Equal: Sylvia Mendez and her Family's Fight for Desegregation by Duncan Tonatiuh, 2014, New York, NY: Abrams. Copyright 2014 by Duncan Tonatiuh.

On the first day, Mr. Kent, the superintendent of the Garden Grove district was questioned. He said that he sent children to the Mexican school to help them improve their English.

That is a lie thought Sylvia. Her English was as good as the English of any of the children at the Westminster School.

“Do you give the children any tests?” asked Mr. Marcus.

Mr. Kent claimed he did. "We do so by talking to them."

That is another lie! Sylvia wanted to yell. No one had questioned her. They rejected her from the Westminster school without asking her a thing (Tonatiuh, 2014, p. 25).

Speeches, essays, nonfiction, science fiction, and dramas are examples of genres in which authors frequently use argumentation. 
With these authorial purposes in mind (narration, information, description, argumentation), we can use applicable criteria to determine quality across children's literature texts (Video. 5.1).

Video 5.1 Determining the Communicative Purpose of Text and Illustration http://www.kaltura.com/tiny/x1tmd

\section{DETERMINING THE COMMUNICATIVE PURPOSE OF TEXT AND ILLUSTRATION}

\section{WITH JENIFER SCHNEIDER}

THE INSIDE, OUTSIDE, AND UPSIDE DOWNS | From Poets and Pop-ups to Princesses

OF CHILDREN'S LITERATURE

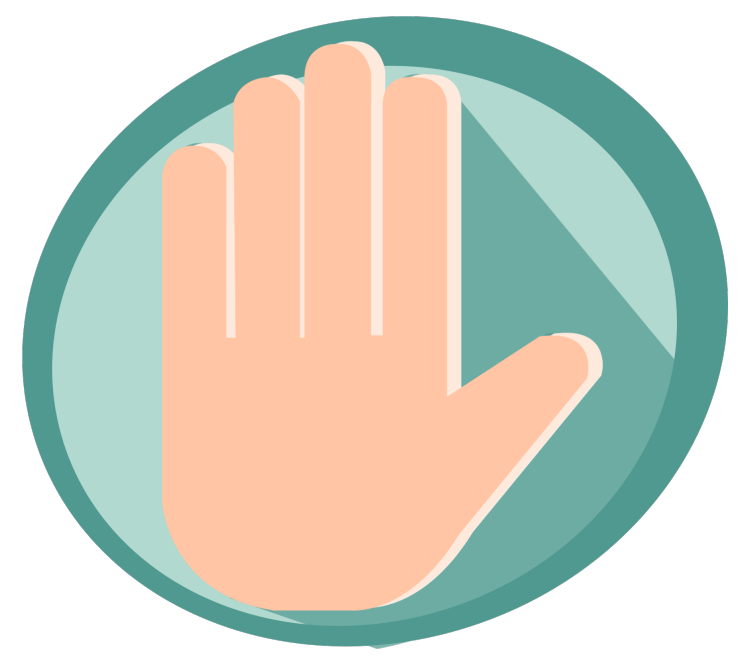

Wait! Not so fast. What about the pictures? In the previous examples, I used the author's rhetorical devices and compositional techniques to determine the communicative purpose of the text. Some of the examples were illustrated, but I focused on the text as the predominant carrier of the message. Picture books are different. Picture books represent the illustrator's intent through visual imagery. What do we do about the pictures? We do the same thing. 


\section{Visual Purpose and Illustrative Style: Another Vehicle for Communication}

Illustrations are created for all of the same purposes described above (narration, information, description, argumentation). The difference between picture books and illustrated texts is the role of the illustrations. Many books include illustrations as cover art, as chapter introductions, or to illustrate selected ideas throughout the text. In picture books, text and images are the conduits of meaning; they work together.

Other forms, other functions:

Convertible, Muscle, Hybrid, Coupe

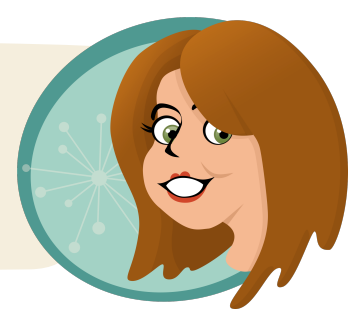

To analyze illustrations, readers typically examine the elements of artistic representation such as line, value, shape, form, space, color, and texture. The reader might also consider the principles of design that integrate the elements such as balance, contrast, movement, emphasis, pattern, proportion, and unity. Several experts have explored these concepts and they offer excellent criteria for "seeing" illustrations and engaging in formal analysis (See Bang, 2000; Moebius, 1986; Nodelman, 1988; Serafini, 2010; Serafini, 2011; Sipe, 1998). Other children's literature texts go into great detail and provide numerous examples to illustrate the elements and principles of artistic representation (e.g., Charlotte Huck's Children's Literature; Kiefer, 2010).

Several online resources are available to help you understand the Artistic Elements:

Line; Value; Shape; Form; Space; Color; Texture;

Principles of Design:

Balance; Contrast; Movement; Emphasis; Pattern; Proportion; Unity.

J. Paul Getty Museum: http://www.getty.edu/education/teachers/building_lessons/ formal_analysis.html

http://www.getty.edu/education/teachers/building_lessons/formal_analysis2.html

The Kennedy Center ArtsEdge:

https://artsedge.kennedy-center.org/educators/how-to/from-theoryto-practice/formal-visual-analysis

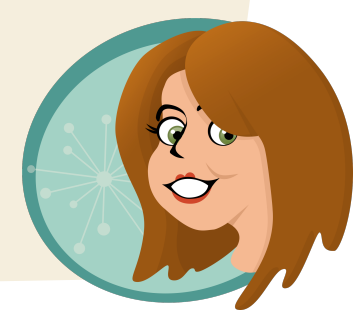


I thought I would go in a different direction. Formal analysis works really well if I want to examine one piece of art, one photograph, one collage. But picture books and illustrated texts are constructed differently. Picture books move. Not in the sense of a motion picture, which captures segments of constructed, yet fluid, movement; but more along the lines of stopmotion animation, which freezes selected moments along a continuum of time. Even so, stop-motion carries a sense of fluidity and a more detailed documentation of movement. Picture books are more episodic. So are illustrated texts. Come to think of it, so is the writing.

"Picture books are more episodic. So are illustrated texts. Come to think of it, so is the writing."

Authors compose text on a blank page and we use their words to comprehend the larger message. Illustrators also create images on a blank canvas and we tend to look more myopically at their techniques. Why not give illustrators the same consideration and look at the broader communicative purposes to determine what they did artistically? Why should I only examine the illustrator's use of color, shape, texture, or pattern?

\begin{abstract}
A caveat-if teachers are using children's literature as a mentor text for teaching writing and/or illustration, then students will examine the author's or illustrator's craft in order to learn from good models. In other words, teachers analyze words, sentence construction, and paragraphing in children's literature in order to help students emulate good writing. This chapter is not about using children's literature mentor texts to teach writing or illustration (that's a different book)-this chapter is about understanding criteria to analyze children's literature for the purposes of knowing what's good and what's a dud. For those of you who are teachers, determining quality is the first step in text selection.
\end{abstract}
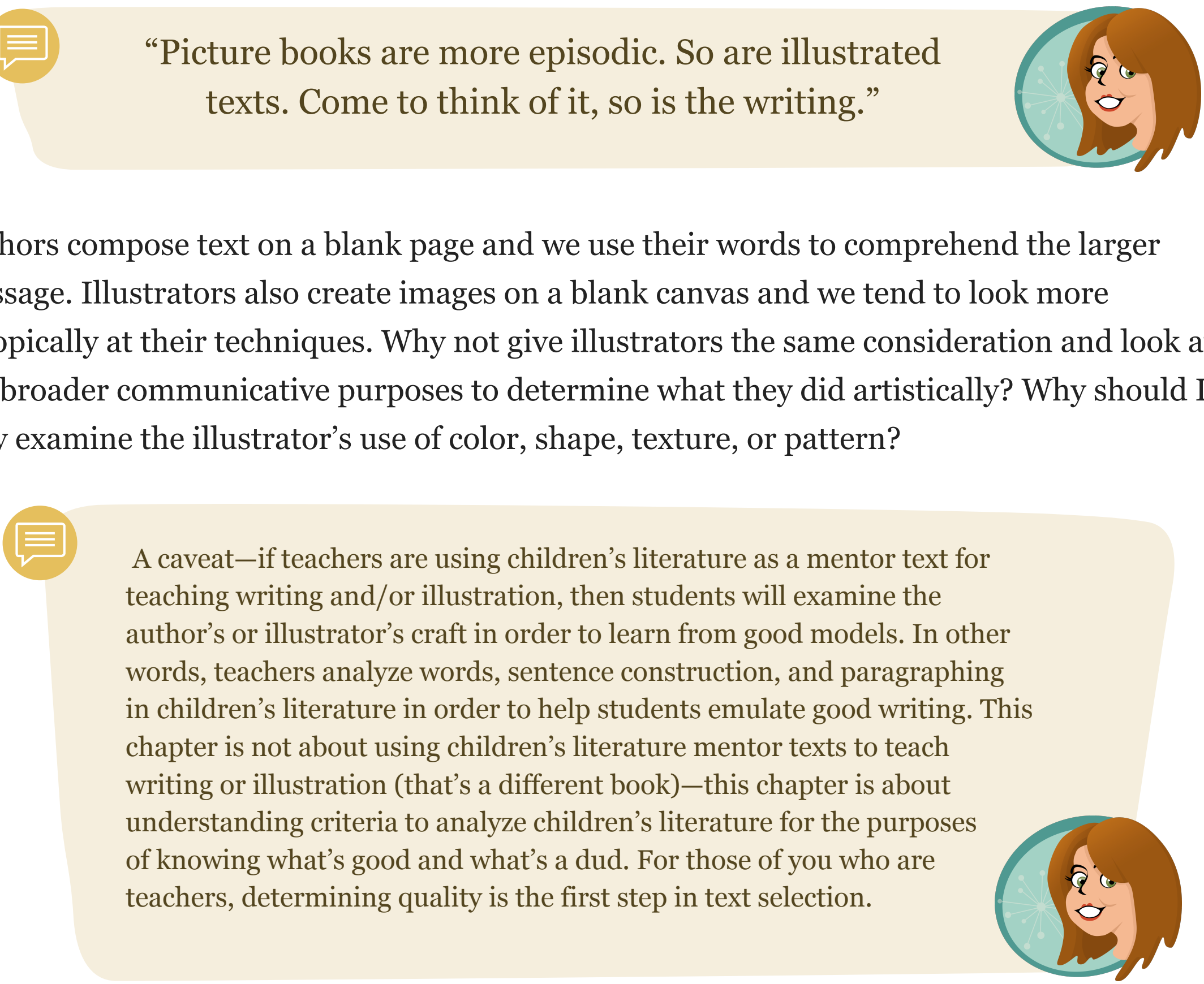

Therefore, let's explore visual analysis as a mode of discourse that indicates the illustrator's intent as well as the way in which the artist communicates the message. 
Narrative Illustration. Narratives include action and events multiplied into a series. In narrative illustrations, events are depicted in a sequence of actions that advance the plot. For example, in Make Way for Ducklings, Robert McCloskey created elaborate illustrations of important incidents as they occurred in chronological order (Figures 5.10 and 5.11).

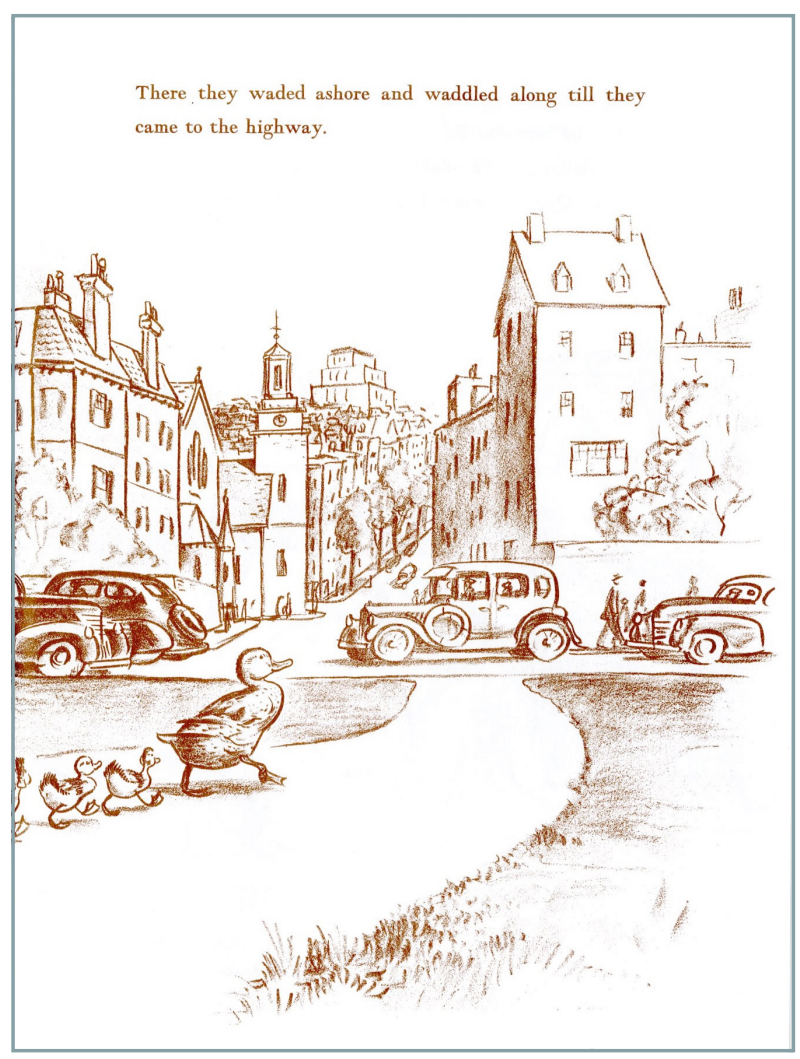

Figure 5.10

A scene from Make Way for Ducklings shows elaborate detail of the setting and tells the story from the perspective of the ducks. Make Way for Ducklings by Robert McCloskey, 1941, New York, NY: Viking Press. Copyright 1969 by Robert McCloskey.

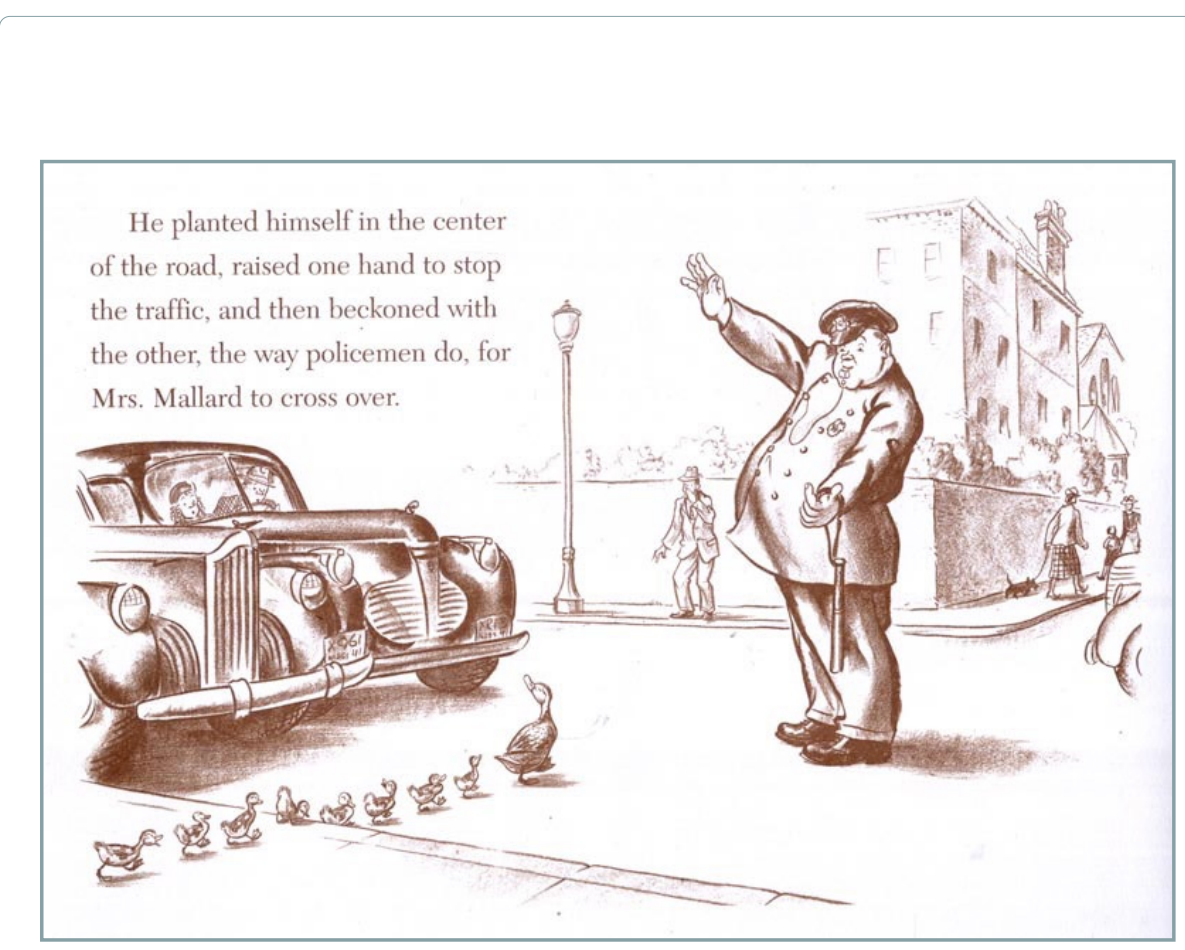

Figure 5.11

Another scene from Make Way for Ducklings by Robert McCloskey shows the progression of the plot. Make Way for Ducklings by Robert McCloskey, 1941, New York, NY: Viking Press. Copyright 1969 by Robert McCloskey.
In other books, the illustrations may be more episodic through the selection of big ideas presented in small moments. In a book about the Civil War, Patricia Polacco's portrayals of simple interactions speak volumes about the characters and their evolution as people in Pink and Say (Figure 5.12). The illustrations tell a visual story in a particular place (setting) with character development occurring within the plot.

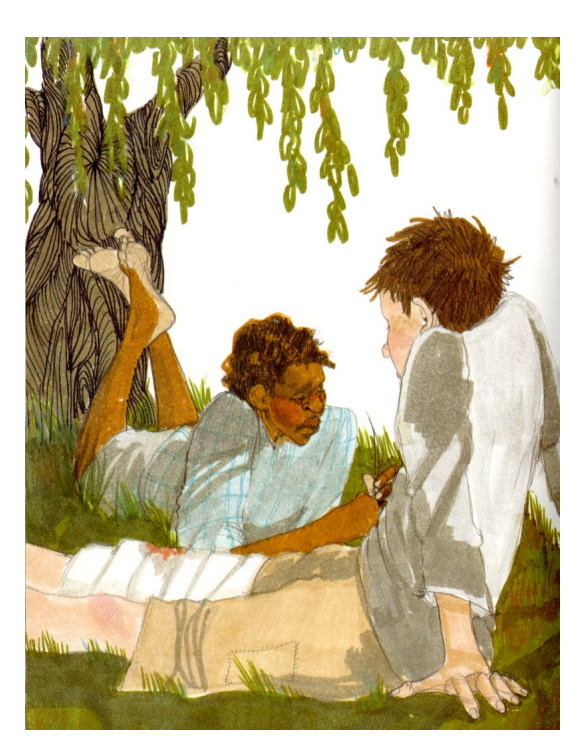

Figure 5.12

Pink and Say tells a big story using illustrations of small details and events. Pink and Say by Patricia Polacco, 1994, New York, NY: Philomel. Copyright 1994 by Patricia Polacco. 
In addition to illustrating plot sequences and character actions, illustrators also narrate by providing the right visual at the right time. In Video 5.2, I share my reading of Olivia, looking specifically at the ways in which Ian Falconer isolated key examples to illustrate the story of a little pig who is good at lots of things. Watch this video to learn how to "read" a picture book by exploring book design, by interpreting the visual illustrations, and by understanding the rhetorical moves of the printed words.

\section{HOW TO READ A PICTURE BOOK STARRING OLIVIA, BY IAN FALCONER}

\section{WITH JENIFER SCHNEIDER}

\section{THE INSIDE, OUTSIDE, AND UPSIDE DOWNS $\mid$ From Poets and Pop-ups to Princesses OF CHLLDREN'S LITERATURE and Porridge}

Overall, narrative illustration tells a story. Yet, just as a writer makes authorial choices with regard to sequencing, point of view, pacing, voice, and tone, the illustrator makes the same choices. The illustrator is not retelling the author's story; the illustrator is creating his or her own visual story. 


\section{Informative Illustration.}

Informational books are defined as those illustrated to present, organize, and interpret documentable, factual material (ALA, nd, Sibert Medal). Informative illustrations replicate these purposes. Often the illustrations provide thick, rich details that are not always readily apparent or interpretable from the text (Figure 5.13). For example, Katharine Roy illustrates the idiosyncrasies of a shark's circulatory system demonstrating how blood impacts body temperature (Figure 5.14). Unless a reader has an extraordinary ability to visualize the internal workings of a shark, the illustrations are essential for the reader's comprehension of the concepts.

Often informative images are realistic, such as the actual photographs and documents used in The Family Romanov: Murder, Rebellion, \& The Fall of Imperial Russia (Figure 5.15). Yet, other books are illustrated to capture a different feeling. For example, In The Right Word: Roget and his Thesaurus, Melissa Sweet chose to emphasize Roget's work, his keeping of lists, and his aggregation of words over time (Figure 5.16), highlighting different scenes and events from his life (Figure 5.17). The spirit of Roget's obsessive collecting and word documentation was interpreted by Sweet's collage illustrations that have the feeling of a junk-drawer or a treasure chest (Figure 5.18).

\section{Figure 5.13}

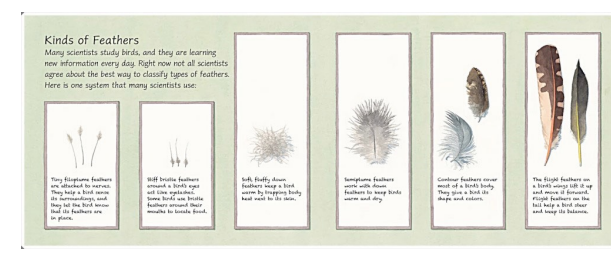

Sarah S. Brannen used panels and labels to highlight the features of different types of feathers in Feathers Not Just for Flying by Melissa Stewart and illustrated by Sarah S. Brannen, 2014, Watertown, MA: Charlesbridge Publishing. Copyright 2014 by Sarah S. Branne

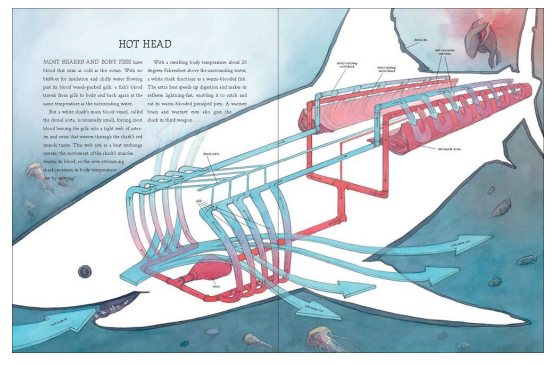

Figure 5.14

Katherine Roy's illustrations provide essential visual details in Neighborhood Sharks: Hunting with the Great Whites of California's Farallon Islands by Katherine Roy, 2014, New York, NY: David Macaulay Studio. Copyright 2014 by Katherine Roy.

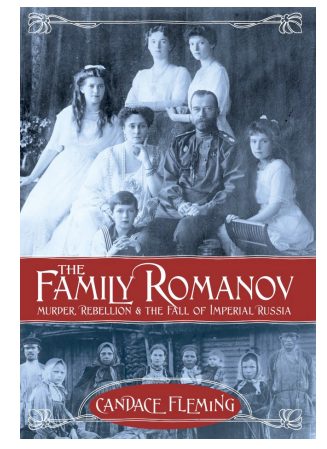

Figure 5.15

The cover image features the use of photographs and primary sources in The Family Romanov: Murder, Rebellion \& the Fall of Imperial Russia by Candace Fleming, 2014, New York, NY: Schwartz \& Wade. Copyright 2014 by Candace Fleming.

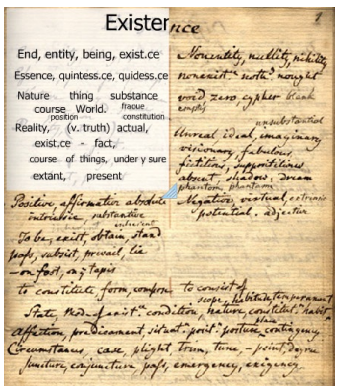

Figure 5.16

Roget's lists are viewable at the Karpeles Manuscript Library. The online site includes an interactive tool that allows users to view the document's transcription

(http://www.rain.org/ karpeles/index.html). Roget's entry for Existence, 1805, Retrieved from http://www.rain.org/ karpeles/rogfrm.html.

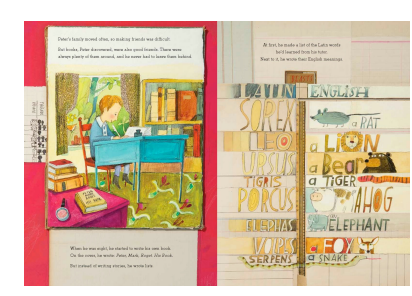

Figure 5.17

Melissa Sweet uses collage to represent Roget's process of collecting words in The Right Word: Roget and his Thesaurus by Jen Bryant and illustrated by Melissa Sweet 2014, New York, NY: Eerdmans Books for Young Readers. Excerpt art copyright 2014 by Melissa Sweet.

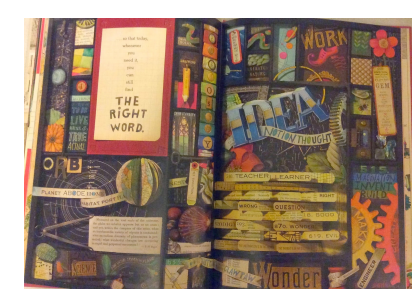

Figure 5.18

Sweet's illustrations are highly detailed and accessible to readers. The Right Word: Roget and his Thesaurus by Jen Bryant and illustrated by Melissa Sweet 2014, New York, NY: Eerdmans Books for Young Readers. Excerpt art copyright 2014 by Melissa Sweet.

Describing Melissa Sweet's illustrations as a junk-drawer might seem derogatory. I don't have this intention. I use this analogy because her illustrations have a lot of visual interest; everything has its place; and it captures and collects the necessities of life. Melissa Sweet's illustrations do just that!

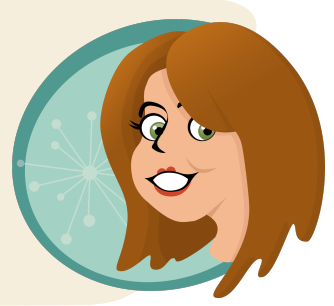


Illustrators, just like authors, use different structures to inform readers. Some informational illustrations are organized by concept (Figure 5.19). Others dramatically recreate sequences of events (Figure 5.20). Still others use captions, comparisons, labels, titles, charts, graphs, fonts, and other text features to convey meaning

(Figure 5.21).

\section{Descriptive Illustration.}

Descriptive illustration is focused on the presentation of elaborative detail. The illustrations provide a visual that corresponds to or extends the details from the text. For example, in Owl Moon, Jane Yolen's language reflects the quiet of the snow and the stillness needed to find an owl in the late night. John Schoenherr's illustrations move beyond the main character's thoughts to reflect her relationship with her father as well as their interactions with the expansiveness of nature (Figure 5.22).

In contrast to Owl Moon, Rosalyn Schanzer uses harsh black and white scratchboard illustrations with striking accents of red to portray the hysteria and horror of the Salem witch trials in Witches! (Figure 5.23). In Owl Moon and Witches!, the illustrations add descriptive details, elucidating themes that are not specifically mentioned in the texts.

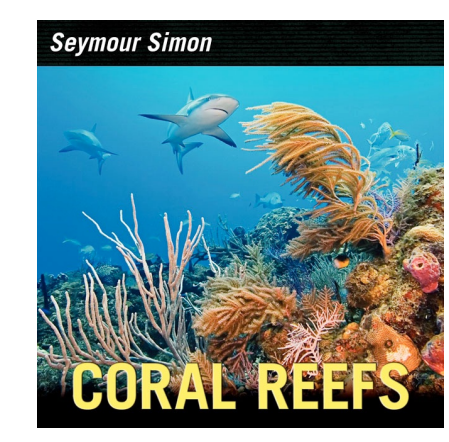

Figure 5.19

Seymour Simon has written approximately 300 books for children. Most of his books focus on a particular concept such as snakes, planets, and coral reefs. Coral Reefs by Seymour Simon, 2013, New York, NY: HarperCollins. Copyright 2013 by Seymour Simon.

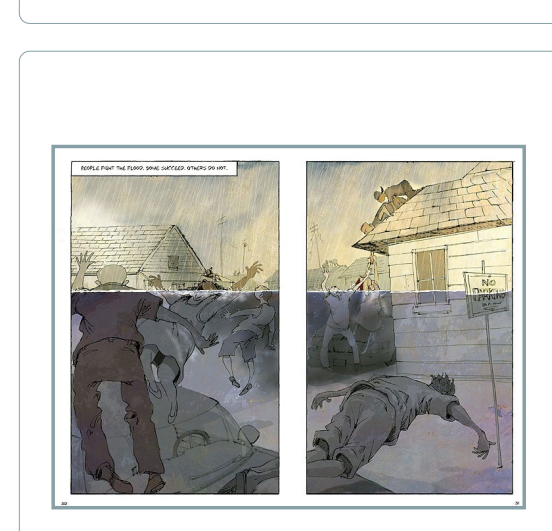

Figure 5.20

In Drowned City, Don Brown illustrates the tragedy of Hurricane Katrina with a perspective that is more disturbing than the media coverage of the storm and its aftermath. Drowned City: Hurricane Kartrina \& New Orleans by Don Brown, 2015, New York, NY: HMH Books for Young Readers. Copyright 2015 by Don Brown.

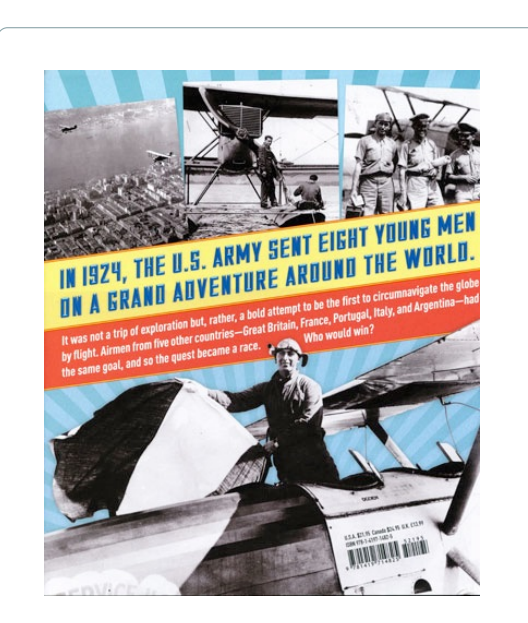

Figure 5.21

Captions, labels, titles, and charts are a few of the text features used in informative illustrations. Excerpt from First Flight Around the World: The Adventures of the American Fliers Who Won the Race by Tim Grove and the National Air and Space Museum, 2015, New York, NY: Henry N. Abrams. Copyright 2015 by Tim Grove and the National Air and Space Museum.

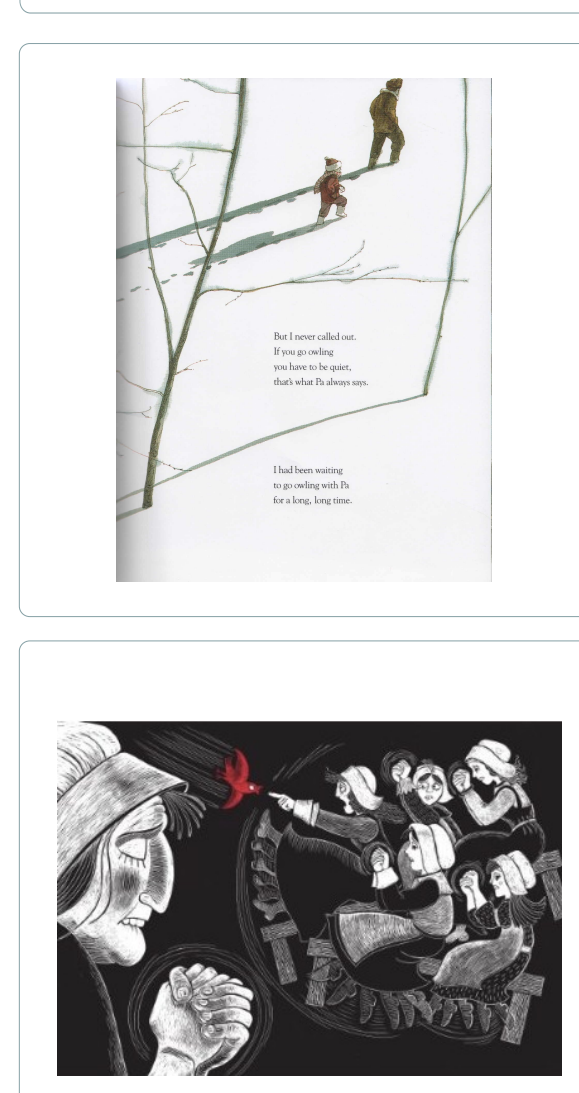

Figure 5.22

John Schoenherr's illustrations for Owl Moon capture more than a story. They explore human interaction in nature. Excerpt from Owl Moon by Jane Yolen and illustrated by John Schoenherr, 1987, New York, NY: Philomel Books. Illustration copyright 1987 by John Schoenherr.

\section{Figure 5.23}

Rosalyn Schanzer uses color, line, and a scratching technique to illustrate the events surrounding the Salem Witch Trials. Excerpt from Witches!: The Absolutely True Tale of Disaster in Salem, by Rosalyn Schanzer, 2011, Washington, DC: National Geographic Books. Copyright 2011 by Rosalyn Schanzer. 
In another example, The Boy Who Loved Math, the title informs the reader that the book is about a boy who loves math, but the illustrations show the depth of his love (Figure 5.24). Illustrator, LeUyen Pham, creates the vivid details of someone who not only loves math, but he lives, breathes, and thinks with math (Figure 5.25). This is what math obsession looks like (Figure 5.26).

\section{Argumentative Illustration.}

Argumentation through illustration is the illustrator's ability to present issues with an evaluative perspective. For example, one of the rhetorical structures for argument is to compare and contrast. Illustrators can make this move as well. In Hey, Little Ant (Figure 5.27), Debbie Tilley uses size differences, along with character gestures and facial expressions, to help the reader understand the ant's argument for why he should not be squashed.

Argumentative illustration also presents a point of view. In Separate is Never Equal: Sylvia Mendez and her Family's Fight for Desegregation, Duncan Tonatiuh could have illustrated Sylvia's courtroom experience from any number of perspectives (from above, close up to the main character, from the judge's bench, from the witness stand), but he chose to place the reader behind Sylvia (Figure 5.28). As readers, when we view the page, we watch the whole scene Figure 5.24
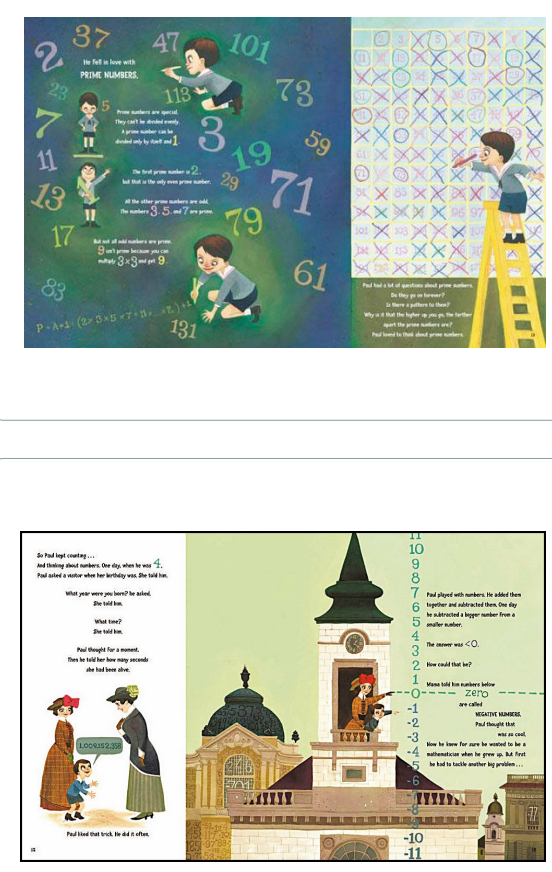

Illustrator, LeUyen Pham, creates the details of math obsession in The Boy Who Loved Math by Deborah Heiligman, 2013, New York, NY: Roaring Book Press. Illustration copyright 2013 by LeUyen Pham.

Figure 5.25

If you know someone who loves math, you will recognize the math-centric behaviors of the main character, Paul Erdõs in The Boy Who Loved Math by Deborah Heiligman, 2013, New York, NY: Roaring Book Press. Illustration copyright 2013 by LeUyen Pham.

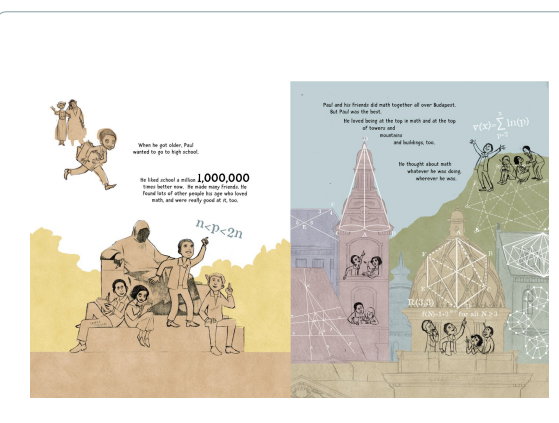

Figure 5.26

Seriously. My husband loves math and he sees the world in numbers and formulas. This is real. The Boy Who Loved Math by Deborah Heiligman, 2013, New York, NY: Roaring Book Press. Illustration copyright 2013 by LeUyen Pham.

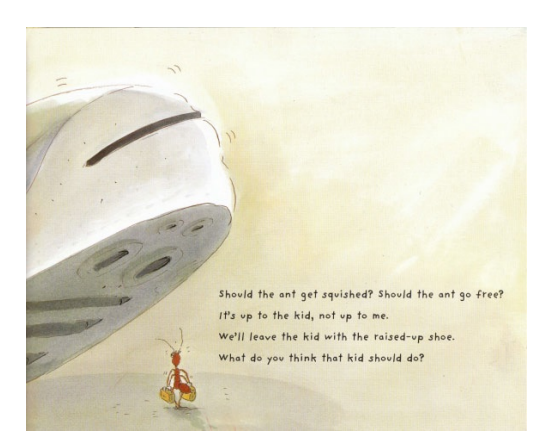

Figure 5.27

Debbie Tilley uses comparison in her illustrations of the characters in Hey, Little Ant by Phillip M. Hoose and Hannah Hoose and illustrated by Debbie Tilley, 1998, New York, NY: Tricycle Press. Illustration copyright 1998 by Debbie Tilley.

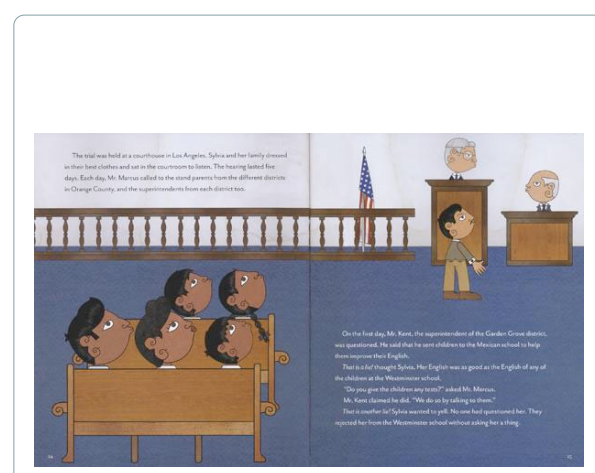

Figure 5.28

Duncan Tonatiuh manipulates the reader's point of view to alter our relationship to the character and our interpretation of the courtroom scene in Separate is Never Equal: Sylvia Mendez and her Family's Fight for Desegregation by Duncan Tonatiuh, 2014, New York, NY: Abrams. Copyright 2014 by Duncan Tonatiuh. unfold as an objective audience even though the words are written from Sylvia's point of view. 
Illustrators use argumentative techniques to appeal to the reader's ethics, reason, and emotions (Figure 5.29). In the classic picture book, The True Story of the Three Little Pigs, Jon Scieszka tells the story of a misunderstood wolf who "accidentally" causes a series of calamities in which pigs must be eaten, otherwise, their carcasses would go to waste. Beginning with the cover, Lane Smith presents the wolf's story as journalistic truth. The wolf is a bespectacled, respectable citizen whose newspaper article is crumpled by a pig's wicked-looking hoof. Whose side are you on?

All genres, including speeches, essays, nonfiction, science fiction, and dramas use argumentation in illustration (Watch Video 5.3). Even poetic texts use argumentative illustration. For example, when you read the title of Douglas Florian's book, Poem Runs, you may not understand the meaning or intention of the text. But take a look at the illustrations (Figure 5.30) and the author's playfulness is apparent as he appeals to the reader's sense of humor.

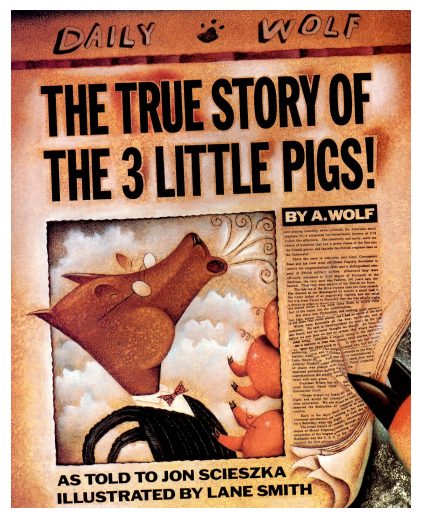

Was it an accidental sneeze or an intentional blow? Illustrators, such as Lane Smith, appeal to the reader's ethics, reason, and Story of the Three Little Pigs by Jon Scieszka and illustrated by Lane Smith, 1989, New York, NY: Penguin. Illustration copyright 1989 by Lane Smith.
Figure 5.29 emotions. Excerpt from The True

\section{Figure 5.30}

Douglas Florian has a series of poetry books (Poem Depot, Poem Runs, Poetrees) in which the illustrations alter the ways in which the titles are read. Cover from Poem Runs by Douglas Florian, 2012, New York, NY: HMH Books for Young Readers. Copyright 2012 by Douglas Florian.

Video 5.3 Visual Purpose and Illustrative Style http://www.kaltura.com/tiny/lfhu3

\section{VISUAL PURPOSE AND ILLUSTRATIVE STYLE}

\section{WITH JENIFER SCHNEIDER}




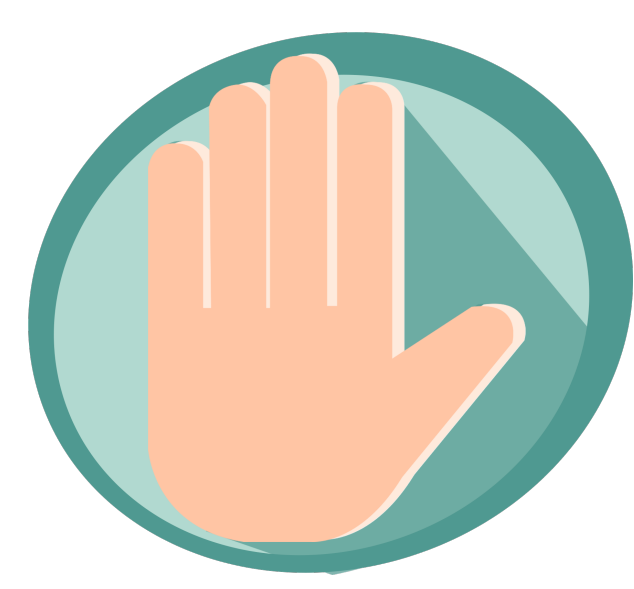

So far we have identified the text's communicative purpose across rhetorical and visual modes. In other words, we determined the literary form of the textual "vehicle" and assessed its intended function.

Next, let's take a look at assorted makes and models to get a sense of the range and variation across different vehicles.

I said I didn't know anything about cars, but I never promised to abandon my analogy. I'm going to stick with it.

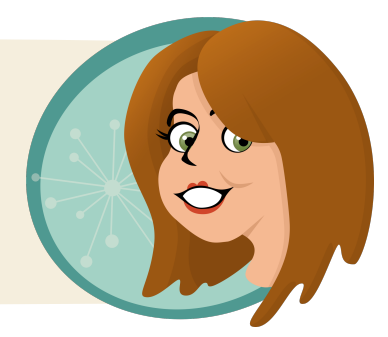

\section{Genres: The Makes and Models of Children's Literature}

Literary genres are categories of text based on any number of different criteria:

literary purpose (narration, information, description, argumentation);

author's tone (humor, serious, unbiased);

content (science topics, social substance, subject matter);

style (prose, poetry, technical);

format (board book, wordless book, novel, games);

length (short story, booklet) etc.

There are many different genres and no single agreement on the number of genres, names of genres, or sub-categories of genres. In other words, "genres" are the categories that make up a taxonomy of children's literature.

The Makes and Models are equivalent to the different vehicle brands (Chevy, Ford, Toyota) and the variations in the forms of each vehicle (Corolla, Camry, Prius).

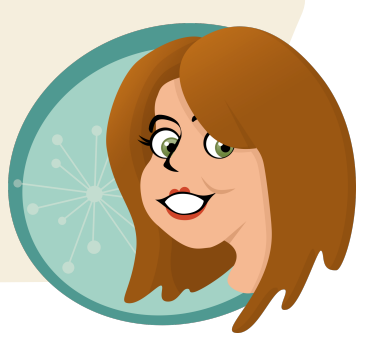


Although many other children's literature textbooks are organized by genre, I chose to organize this book by purpose. Here's why-I want you to know how to evaluate children's literature quality. Rather than providing extensive details about choosing books across the field of children's literature, which can include 15-20+ genre categories (depending on who's counting), I wanted a more simplified approach and I chose to organize around four major communication purposes. However, genre knowledge is important. Therefore, you need to familiarize yourself with some of the most common genre categories as well as some of the authors and illustrators who write or draw in particular genres.

"Genres" are the categories that make up a taxonomy of children's literature. This is why I chose to use "rhetorical purpose" to help you determine quality children's literature. It's easier to familiarize yourself with four categories of evaluative criteria rather than use different criteria across 15 to $20+$ genres.

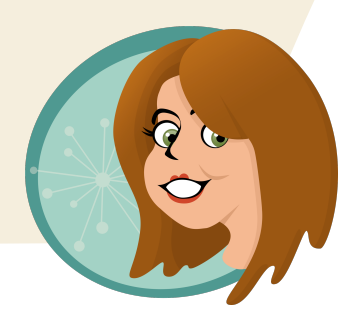

Picture books. Picture books are stories or content presented through text and illustrations. All topics are covered. The author's words and the illustrator's images are interwoven and equally important. Picture books are written for any purpose and on all topics.

Notable Authors and Illustrators.

Dr. Seuss, Tomie dePaola, Eric Carle (Figure 5.31), Maurice Sendak, Jane Yolen, Jerry Pinkney, Chris Van Allsburg, Mo Willems, Judith Viorst, Kadim Nelson, Beatrix Potter, Floyd Cooper (Figure 5.32), Henry Cole, Doreen Cronin, Chris Raschka, David Diaz, Jon Scieszka, Robert McCloskey, Leo Lionni, Ezra Jack Keats, Paul Goble, Eve Bunting, Marc Browne, Anthony Browne, Eric Velasquez, Betsy Lewin, Ted Lewin, Donald Crews, Anno, Pat Hutchins, Molly Bang, Helen Oxenbury.

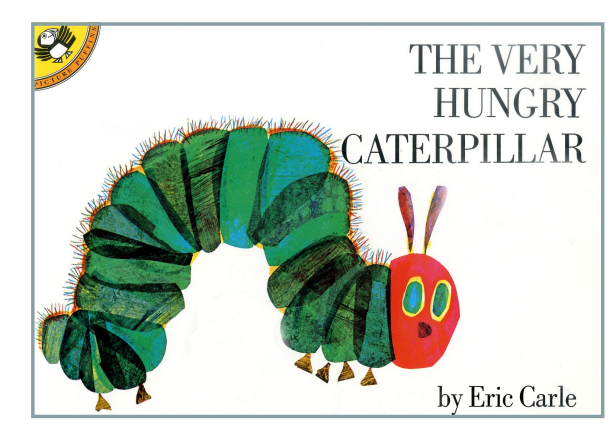

Figure 5.31

Magical, beautiful, interesting, and just overall lovely! I'm sure you have read The Very Hungry Caterpillar by Eric Carle, 1969, New York, NY: World Publishing Company. Image from a later publication, 1982, New York, NY: Penguin. Copyright 1969/1982 by Eric Carle.

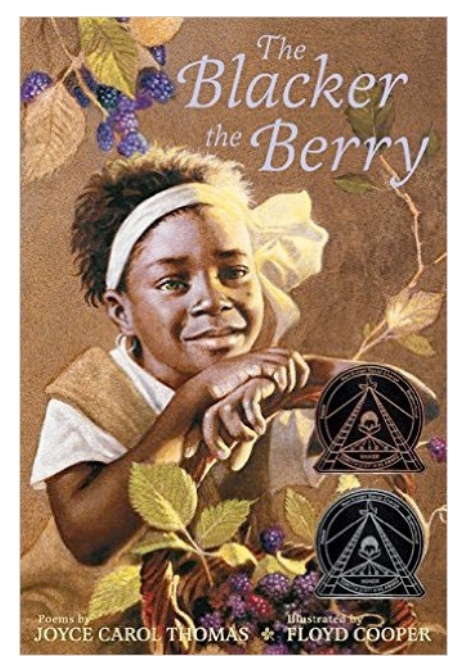

Figure 5.32

I don't know of any artist who paints faces like Floyd Cooper. I am drawn to his artwork. He is able to capture an internal spirit that is indescribable. This example is a book of poetry The Blacker the Berry by Joyce Carol Thomas and illustrated by Floyd Cooper, 2008, New York, NY: Amistad. Cover art copyright 2008 by Floyd Cooper. 


\section{Best-of lists.}

- School Library Journal's Top 100 Picture Books: Great overview of famous books

- http://www.slj.com/wp-content/uploads/2012/08/SLJ Fuse8 Top100 Picture.pdf

- Goodreads: Lists categories of "best” picture books (Indie, modern, 'green', bedtime)

- https://www.goodreads.com/list/tag/picture-books

Comment: OK this is very difficult. I could go on and on and on with lists of authors and illustrators. I've tried to select people with different styles and who have created several books-- some old and some new. So view my recommendations as a starter list. Then create your own.

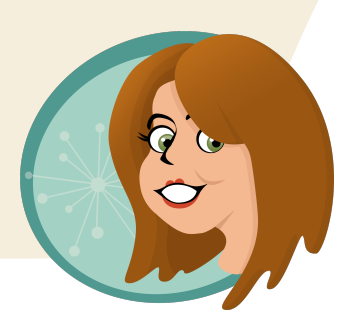

Wordless books. Wordless books look like picture books, but they do not have words. The story or information is shared through illustrations or other images. The images can be simple or elaborate and created in all mediums, but the meaning is in the illustrations. All topics are covered.

Notable Authors and Illustrators. David Wiesner (Figure 5.33), Henry Cole, Marla Frazee, Raul Colon, Chris Raschka, Jerry Pinkney, Molly Idle, Barbara Leyman Mercer Mayer, Brinton Turkle, Alexandra Day, Peter Spier, Raymond Briggs, Emily McCully.

\section{Best-of lists.}

- Goodreads Wordless Picture Books: Nice overview of popular wordless books

- https://www.goodreads.com/list/show/ 722. Wordless Picture Books

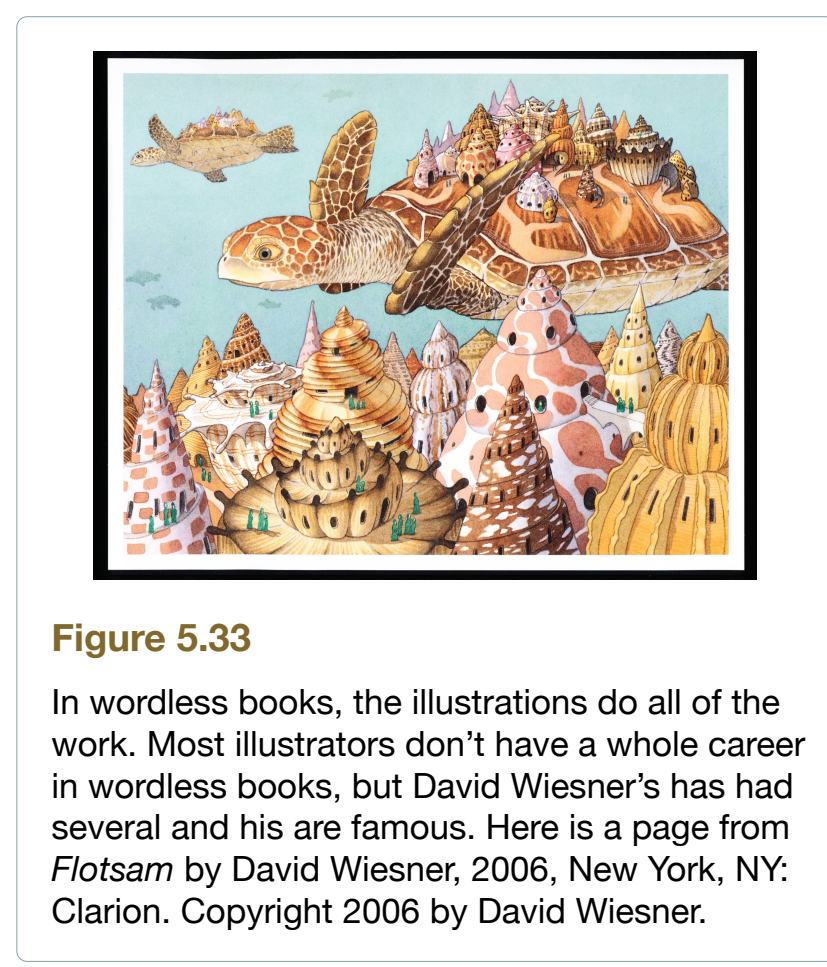

- Children's Books Guide, Wordless: Top 10 list of wordless books

- http://childrensbooksguide.com/wordless 
Poetry. Poetry is published in anthologies or single-authored poem books. Single poems are often turned into picture books. Poetry expresses feelings, thoughts, and events in brief and meaningful ways. Poetry is rhythmic, emotional language and it is written to cover the range of human experience.

\section{Notable Authors and Illustrators.}

Arnold Adoff, Eloise Greenfield (Figure 5.34), Myra

Cohn Livingston, Jack Prelutsky, Shel

Silverstein, Douglas Florian, Nikki Giovanni, Nikki Grimes, Langston Hughes, A.A.Milne, Byrd Baylor, Lee Bennett Hopkins, Paul Fleischman, Judith Viorst, Pat Mora, Eve Merriam, Marilyn Singer, X.J. Kennedy, Kenn Nesbitt, J. Patrick Lewis (Figure 5.35).

\section{Best-of lists.}

- School Library Journal, Introducing Students to NCTE's Notable Poetry Titles

- http://www.slj.com/2014/04/collectiondevelopment/introducing-students-to-nctesnotable-poetry-titles/

- Goodreads Best Children's Poetry Books

- http://www.goodreads.com/list/show/ 1340.Best_children_s_poetry_books

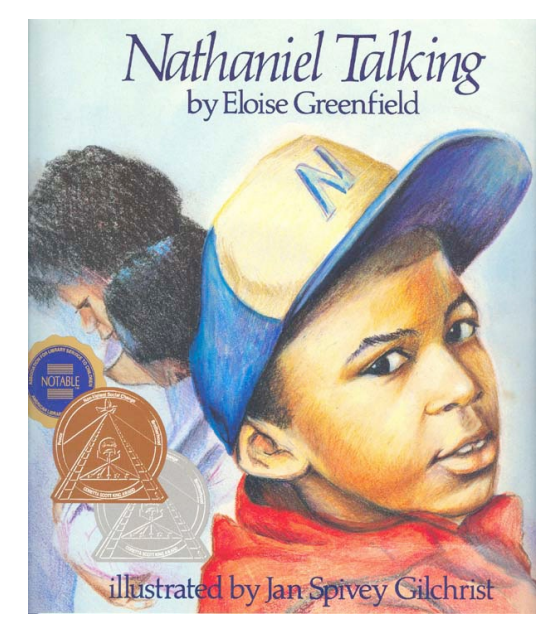

Figure 5.34

Eloise Greenfield's poetic texts are written from different perspectives and focus on unique characters, but they all relate powerful emotions and stories. Nathaniel Talking is one example of Eloise Greenfield's many contributions. Nathaniel Talking by Eloise Greenfield and illustrated by Jan Spivey Gilchrist, 1998, London, England: Writers \& Readers. Cover art copyright 1998 by Jan Spivey Gilchrist.

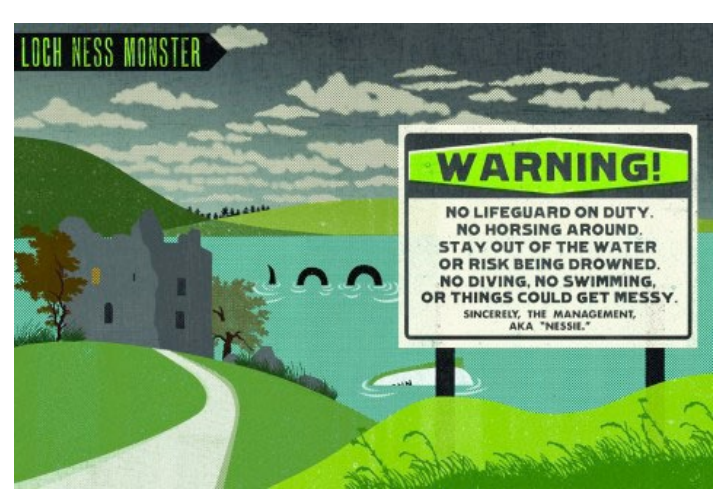

Figure 5.35

J. Patrick Lewis and Kenn Nesbitt are award-winning, prolific poets. In Bigfoot is Missing, they take on the creatures of childhood nightmares. MinaLima's illustrations play with all of the hype. Bigfoot is Missing by J. Patrick Lewis and Ken Nesbitt and illustrated by MinaLima, 2015, New York, NY: Chronicle Books. Illustration copyright 2015 by MinaLima. 
Traditional literature. Traditional literature is the label for stories that have been passed from generation to generation through oral storytelling. These folk tales, fables, myths, legends, and tall tales may be published as single story picture books (Figure 5.36) or in collections and anthologies (Figure 5.37). Most people associate the Brothers Grimm, Joseph Jacobs, and Charles Perrault as the "writers" of these stories, but they were more like collectors and interpretive transcribers. They collected the stories and published them, with their own twists and spins, of course, but they didn't "create" them.

Sometimes writers and illustrators use traditional stories to create spin-offs, parodies, or fractured fairy tales (Jon Scieszka and Lane Smith are a famous duo). There are many variations. Most often readers have concepts of the Disney versions of these tales. Read the older versions and you will see a huge difference.

Notable Authors and Illustrators. Modern variations or retellings by Arnold Lobel, Paul Galdone, Steven Kellogg, Jon Scieszka, Virginia Hamilton, James Marshall (Figure 5.38).

\section{Best-of lists.}

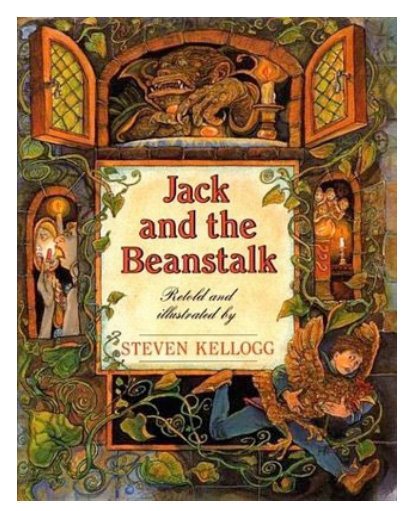

Figure 5.36

Steven Kellogg wrote and illustrated several tall tales and legends as separate books. One example is Jack and the Beanstalk by Steven Kellogg, 1997, New York, NY: HarperCollins. Copyright 1997 by Steven Kellogg.

- LibGuide, Traditional Literature: Comprehensive review of traditional literature with a description of the genre and sub-categories

- http://libraryschool.libguidescms.com/content.php?pid=342934\&sid=2804433

- Goodreads: Popular Traditional Literature Books

- http://www.goodreads.com/shelf/show/traditional-literature

- School Library Education Consortium: Traditional Literature

- http://uwsslec.libguides.com/c.php?g=186921\&p=1236147

- Collection of Grimm Brothers' Tales compiled, translated, and classified by D.L. Ashliman. 
Fantasy. Fantasy stories are most often presented as novels, although they often include chapter illustrations or sporadic illustrations throughout. Fantasy is a category of fiction (the story is created by the writer) except the events are fantastical and cannot happen in real life. Fantasy is imaginative and borrows elements of style, characters, and themes from traditional literature as well. For an excellent overview of different types of fantasy, click here: http://www.yalsa.ala.org/thehub/2013/04/03/discovering-your-brand-of-fantasy/.

Notable Authors and Illustrators. Madeleine L'Engle, C.S. Lewis, Susan Cooper, R.L. Stine, Lois Lowry, Natalie Babbitt, Roald Dahl (Figure 5.39), Jon Scieszka, P.L. Travers, Mary Norton, Lloyd Alexander, Hans Christian Andersen, J.K. Rowling, Neil Gaiman.

\section{Best-of lists.}

- Goodreads Best Children's Fantasy (under 10)

- http://www.goodreads.com/list/show/ 461. Best Children s Fantasy

- School Library Journal Middle Grades

Fantasy (ages 10-13, easier to read)

- http://www.slj.com/2012/11/collectiondevelopment/focus-on-collection-development/ middle-grade-fantasy-believe-it-focus-on-believe-it-november-1-2012/

- NPR's Top 100 Science Fiction \& Fantasy books (young adult)

- http://www.listchallenges.com/npr-top-100-science-fiction-and-fantasy-books

Contemporary Realistic Fiction. Contemporary realistic fiction stories deal with all aspects of life within current or recent times, usually set within the parameters of a generation. However, some books begin as contemporary fiction, and due to their longevity, they transfer toward the historic. For example, many of Judy Blume's novels are set in the early 1970's before cassette tapes, CD's, and iPads. At some point, books that reference rotary dial phones will lose their contemporary feel. Contemporary realistic fiction is often referred to as a collection of "problem novels" because they deal with a range of subject matter from drug abuse and suicide to family problems and learning disabilities. 
Notable Authors and Illustrators. Lois Lowry, Judy Blume, Walter Dean Myers (Figure 5.40), Gary Paulsen, Avi, Gary Soto, Katherine Paterson, Johanna Hurwitz, Cynthia Rylant, Phyllis Reynolds Naylor, John Green, Sharon Draper.

\section{Best-of lists.}

- Goodreads Best Young Adult Realistic Novels

- http://www.goodreads.com/list/show/ 8460.Best Young Adult Realistic Novels

- Goodreads Popular Children's Realistic Fiction Books

- http://www.goodreads.com/shelf/show/childrensrealistic-fiction

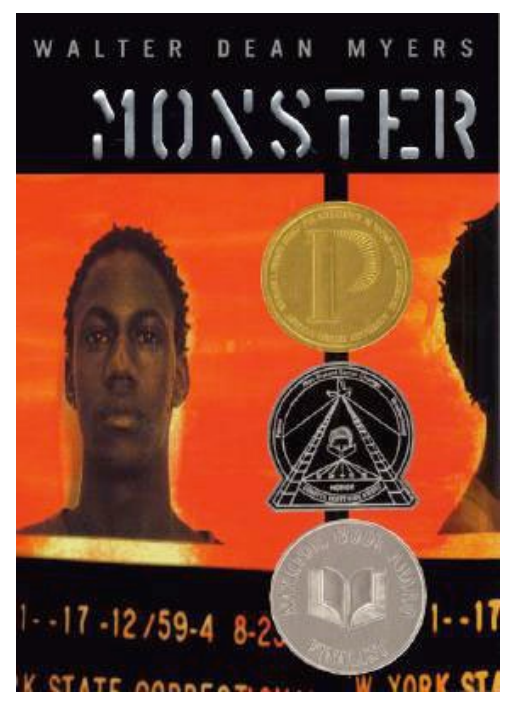

Figure 5.40

One of the most important and impactful writers of contemporary fiction is Walter Dean Myers. Although his books span 40 years, his stories are relevant today. One award winning example is Monster by Walter Dean Myers and illustrated by Christopher Myers, 1999, New York, NY: HarperCollins. Cover art copyright 1999 by Christopher Myers.

- YALSA (Young Adult Library Services Association) Best Fiction for Young Adults Archive: Search by year

- http://www.ala.org/yalsa/2015-best-fiction-young-adults

Historical fiction. Historical fiction is the label for stories that are set in the past. Exactly how far in the past is debatable. Does the book reference cell phones, rotary phones, or no phones? Some people set the cut-off date at 25 years, or a generation. Some people set an historical marker such as the Civil Rights Act. Others use the year of the reader's birth. There isn't a correct answer to what makes fiction historical, but I tend to use the reader's birth as the general line for what "feels" historical; it's relative. Another issue in categorizing historical fiction is the author's intention. Some books get old and they become historical; whereas new historical fiction is written with contemporary insight and reflection on the past. The whole point is that historical fiction is set in the past and it provides insight into a different time period. Historical facts may or may not be used but the text must accurately reflect the historical time period in which it is set. Most of all, historical fiction must tell a good story. 


\section{Notable Authors and Illustrators.}

Katherine Paterson (Figure 5.41), Mildred Taylor (Figure 5.42), Laura Ingalls Wilder, Lois Lowry, Lawrence Yep, Jean Fritz, Patricia MacLachlan, Paul Fleischman, Avi, Scott O’Dell, Jane Yolen, James Collier.

\section{Best-of lists.}

- Pinterest Collection of Best Historical Fiction for Kids

- https://www.pinterest.com/pragmaticmom/ best-historical-fiction-for-kids/

- Keene Public Library: Search a list of historical fiction sorted by setting/ location

- http://keenepubliclibrary.org/library/kids/ historicalfiction

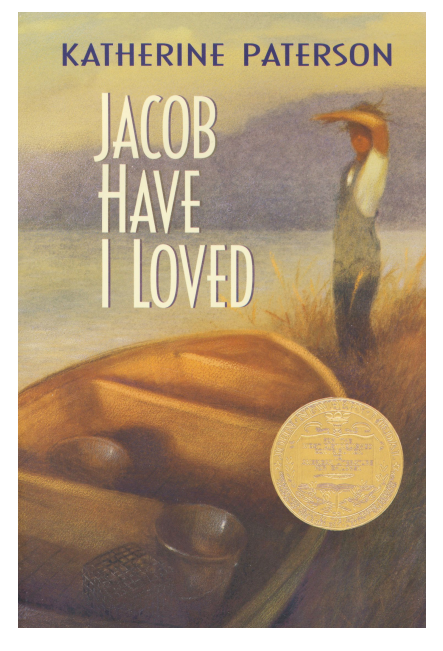

\section{Figure 5.41}

Katherine Patterson is probably best known for writing Bridge to Terebithia or The Great Gilly Hopkins, but my favorite book of all time is Jacob Have I Loved. I have read it over and over again. This is an older cover, but it's the one I love. Jacob Have I Loved by Katherine Paterson, 1980, New York, NY: HarperCollins. Cover art copyright 2007 by Chris Sheban.

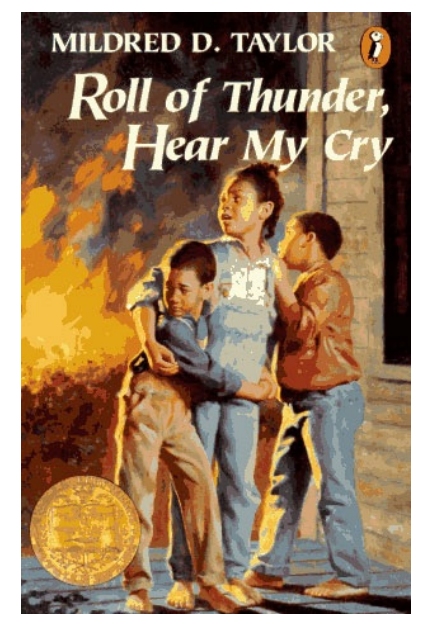

Figure 5.42

Roll of Thunder, Hear My Cry is one of a series of novels set during the time of segregation in the US. Roll of Thunder, Hear My Cry by Mildred Taylor, 1976, New York, NY: Dial Books.

Frontispiece copyright 1976 by Dial Books.

- Notable Social Studies Trade Books: Provides 15 years of notable lists, although some of the books are not "historical fiction."

- $\underline{\text { http://www.socialstudies.org/notable }}$

Graphic novels/texts. Graphic novels are compilations and original works published in a sequential art format. They are reminiscent of cartoons or comic books and they can have varying amounts of text. They can feature fictional, nonfiction, descriptive, or argumentative content.

\section{Notable Authors and Illustrators.}

Dav Pilkey, G. Neri (Figure 5.43), Jeff Kinney, Jullian Tamaki (Figure 5.44), Hope Larson, Lucy Knisley, Faith Erin Hicks, Kevin O’Malley.

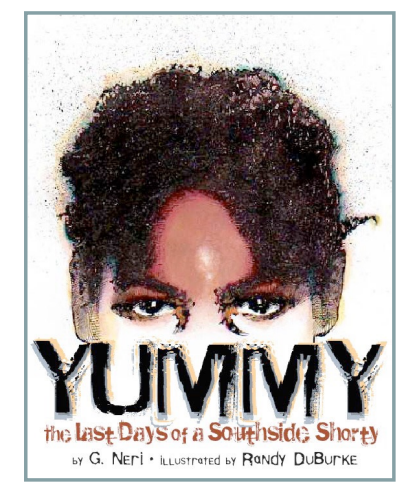

\section{Figure 5.43}

Neri writes all types of fiction, but Yummy was one of the first graphic novels I read. Yummy by G. Neri and illustrated by Randy DuBurke, 2010, New York, NY: Lee \& Low Books. Cover art copyright 2010 by Randy DuBurke.

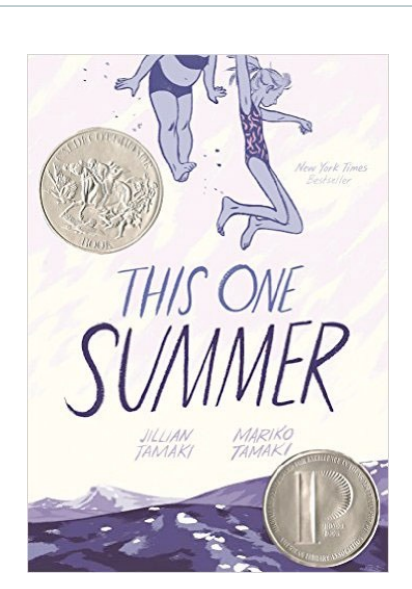

\section{Figure 5.44}

Graphic novels are insanely popular for young adults. The illustrations are elaborate and intense with developed characters and quick dialogue. Jullian Tamaki created This One Summer with her cousin, Mario Tamaki. This One Summer by Jullian Tamaki and Mario Tamaki, 2014, New York, NY: First Second Books. Copyright 2014 by Jullian Tamaki and Mario Tamaki. 


\section{Best-of lists.}

- ALA Graphic Novels Reading Lists

- http://www.ala.org/alsc/graphicnovels2013

- Goodreads Best Graphic Novels for Children

https://www.goodreads.com/list/show/5038.Best Graphic Novels for Children

- School Library Journal Comic Relief: Thirty-nine graphic novels that kids can’t resist

๑ http://www.slj.com/2011/07/collection-development/comic-relief-thirty-nine-graphic-novels-thatkids-cant-resist/\#

- Pinterest Best Graphic Novels

- https://www.pinterest.com/pragmaticmom/bestgraphic-novels/

- First Second Books is a publisher of graphic novels and their website highlights creators and collections of graphic novels for all ages.

- http://www.firstsecondbooks.com/

Biography. Biographies are fictionalized or authentic stories about a real person. Biographies can appear in picture book, novel, or information book formats.

Notable Authors \& Illustrators. David A. Adler (Figure 5.45), Jean Fritz, Diane Stanley, Robert Lawson, Russell Freedman, Aliki, Kadir Nelson (Figure 5.46), Jennifer Fisher Bryant, Jacqueline Briggs Martin, Jeanette Winter, Kathleen Krull, Matt de la Pena.

\section{Best-of lists.}

- Goodreads Popular Children's Biography Books

- http://www.goodreads.com/shelf/show/childrens-biography

- YALSA Booklists for Biography: An expansive lists of biographies that covers all people and time periods.

- http://www.ala.org/yalsa/booklistsawards/booklists/ outstandingbooks/biographyoutstanding

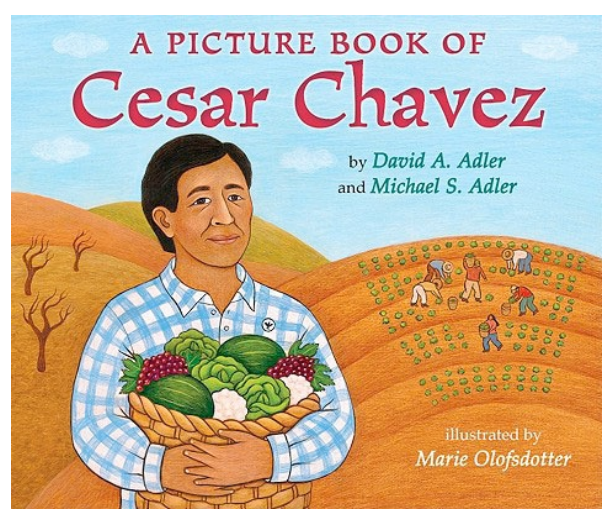

Figure 5.45

David Adler is a prolific writer of biographies. Check out A Picture Book of Cesar Chavez by David A. Adler and Michael S. Adler and illustrated by Marie Olofsdotter, 2011, New York, NY: Holiday House. Cover art copyright 2011 by Marie Olofsdotter.

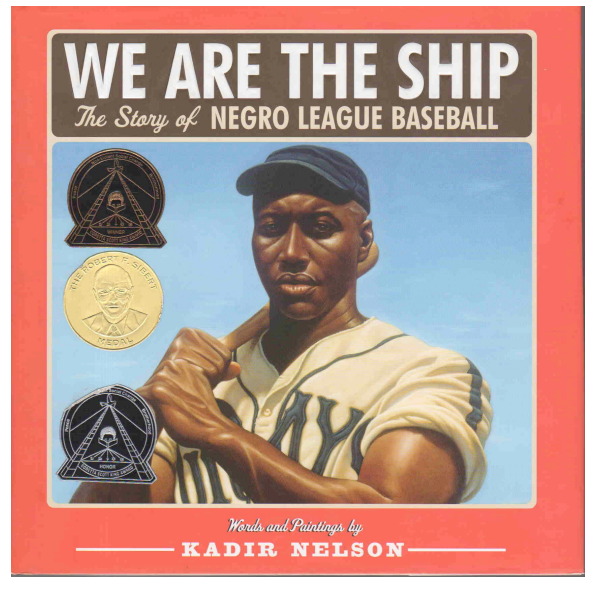

Figure 5.46

Kadir Nelson creates amazing illustrations and he also writes incredible tributes for important individuals. One example is We Are The Ship: The Story of Negro League Baseball by Kadir Nelson, 2008, New York, NY: Jump at the Sun. Copyright 2008 by Kadir Nelson. 
Information. In information or nonfiction books, text is the primary source of information but pictures may play an equal role and they are usually desired. Text and pictures must be accurate, authentic and current. Information books cover a range of topics from history to science to culture.

Notable Authors and Illustrators. Seymour Simon, Russell Freedman, Kadir Nelson, Peter Sis, Joanna Cole, Gail Gibbons (Figure 5.47), Aliki, David Macaulay, Vicki Cobb, Susan Campbell Bartoletti, Jim Murphy, Marc Aronson.

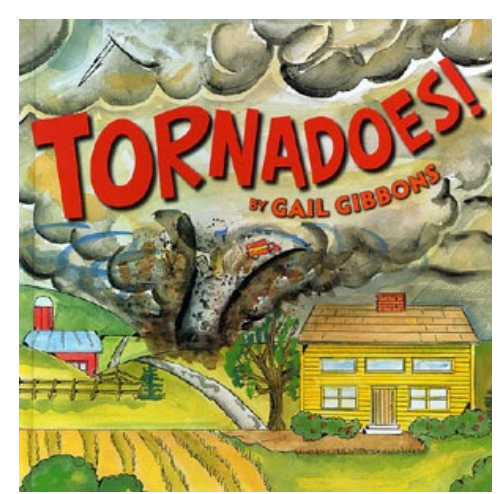

Figure 5.47

Gail Gibbons writes information books for youth of all ages, but she is particularly strong at creating concept books for young children. She writes about a range of topics as well. Tornadoes by Gail Gibbons, 2010, New York, NY: Holiday House. Copyright 2010 by Gail Gibbons.

\section{Best-of lists.}

- Goodreads Best Children's Nonfiction: Great list of favorites from different years

- http://www.goodreads.com/list/show/1557.Best Children s Nonfiction

- Pinterest Best Nonfiction for Kids

- https://www.pinterest.com/pragmaticmom/best-non-fiction-for-kids/

- YALSA Nonfiction Award for notable information books for young adults. Listed by year of publication/award.

- $\underline{\text { http://www.ala.org/yalsa/booklistsawards/bookawards/nonfiction/previous }}$

- Time Magazine's All Time 100 Best Nonfiction: Not necessarily for children, but definitely for young adults

- http://www.goodreads.com/list/show/ 12719.Time Magazine s All TIME 100 Best Non Fiction Books

Diverse books. Children's literature is a window, a mirror, and a map (Sims-Bishop, 1990; Myers, 2014). It is important for children and young adults to read realistic portrayals of people who share similar identities. For these reasons, books are labeled as multicultural books or they are labeled with specific markers to promote the inclusion of diverse characters from different races, classes, nations, and genders. Maybe we won't need labels, but for now, the world of children's literature is still "all white" (Horning, 2014; Larrick, 1965), and the labels bring attention to the issue that \#WeNeedDiverseBooks 
Notable Authors and Illustrators. Floyd Cooper, Kadir Nelson, G. Neri, Jacqueline Woodson, Eloise Greenfield, Pat Mora, Nikki Grimes, Angela Johnson, Allen Say (Figure 5.48), Ed Young, Shaun Tan, Matt de la Pena.

\section{Best-of lists.}

- School Library Journal: \#WeNeedDiverseBooks Realistic Fiction with Diverse Protagonists

- http://www.slj.com/2014/10/reviews/spotlight/ weneeddiversebooks-realistic-fiction-with-diverseprotagonists-slj-spotlight-2/

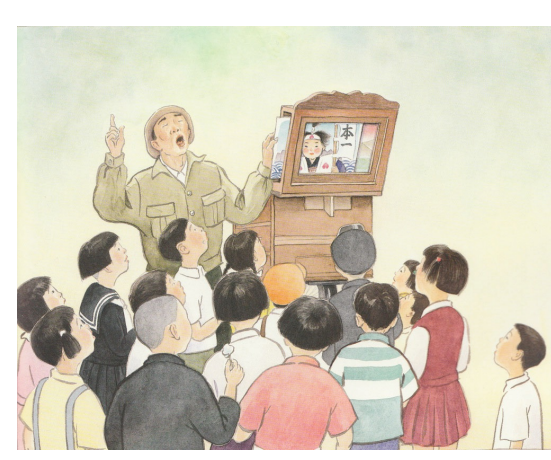

Figure 5.48

Allen Say often creates paintings and tells stories that reflect his Japanese heritage. He won the Caldecott for Grandfather's Journey, which is a must-read about his grandfather's emigration to the US, but he has many other books as well. Kamishibai Man is about a man who performs the dying art of paper theater. Kamishibai Man by Allen Say, 2005, New York, NY: HMH Books for Young Readers. Copyright 2005 by Allen Say.

- We Need Diverse Books

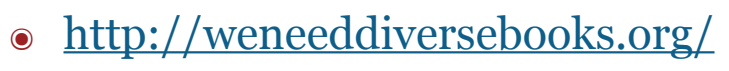

- Book Dragon: Books for the Multi-Culti Reader, sponsored by the Smithsonian Asian Pacific American Center

- http://smithsonianapa.org/bookdragon/about/

- Kids Like Us is an organization that promotes literacy learning of children in city schools and city neighborhoods. You can browse for books by age, genre, gender, and race.

- http://www.kidslikeus.org/books/

- Pat Mora (author) has collected a list of Latino Authors and Illustrators

- http://www.patmora.com/sampler-latino-authors-illustrators-for-children-ya/

- Valerie Knight, a librarian at Wayne State College created an excellent guide to books that reflect religious diversity as well as a guide to books about family diversity and social issues

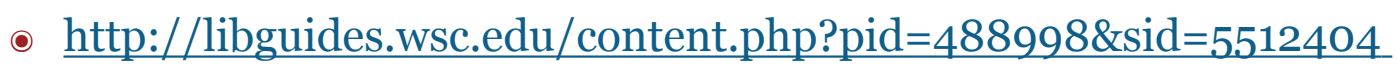

- http://libguides.wsc.edu/content.php?pid=488998\&sid=4010447 
Many languages literature. Not everyone speaks English, and children need books written in a language that is comfortable and easy for them. In addition, many children who speak English are also learning different languages. They could benefit from reading children's books written in other languages. Many languages literature includes books specifically written in other languages as well as books translated into different languages.

Notable Authors and Illustrators. Maria Teresa Andruetto, Victor Carvajal, Edna Iturralde, Jordi Sierra i Fabra, Alma Flor Ada (Figures 5.49 \& 5.50), Bibi Dumon Tak.

\section{Best-of lists.}

- International Children's Digital Library: A searchable database for books written in many languages

\section{- http://en.childrenslibrary.org}

- ALA Batchelder Award: Lists of the most outstanding children's book originally published in a language other than English in a country other than the United States, and subsequently translated into English for publication in the United States.

- http://www.ala.org/alsc/awardsgrants/bookmedia/batchelderaward

- S-Collection: Foreign Language \& Bilingual Children's Books, find books in French, Spanish, Navajo, etc. You can also find translations.

- http://www.library.illinois.edu/sshel/s-coll/findbks/s-collbibs/forlang.htm

- http://www.childrensbooksonline.org/library-translations.htm
Figure 5.49

Alma Flor Ada writes books in English that focus on Latina/o culture. My Name is Maria Isabel is about a girl whose teacher calls her Mary, not Maria, and the struggle the child feels about her name and her identity. My Name is Maria Isabel by Alma Flor Ada and illustrated by K. Dyble Thompson, 1995, New York, NY: Atheneum Books for Young Readers. Cover art copyright by K. Dyble Thompson.

\section{Figure 5.50}

Alma Flor Ada translates children's books from English to Spanish. She translated My Name is Maria Isabel into Me Llamo María Isabel by Alma Flor Ada and illustrated by K. Dyble Thompson, 1996, New York, NY: Atheneum Books for Young Readers. Cover art copyright by K. Dyble Thompson. 
Classics. Classics are books from any genre that have stood the test of time. They should tell good stories and have well-constructed plots, worthwhile themes, and convincing characterization.

\section{Notable Authors and}

Illustrators. J.M. Barrie, C.S.

Lewis, J.R.R. Tolkien, Beatrix

Potter (Figure 5.51), Maurice Sendak

(Figure 5.52), Beverly Cleary, Shel

Silverstein, Ludwig Bemelmans,

Judy Blume, A.A. Milne.

\section{Best-of lists.}

- New York Public Library 100 Books/10o Years: A review of best loved books in alphabetical order

- http://www.nypl.org/ childrens10o

\section{Figure 5.51}

You can download Beatrix Potter's books for free from Project Gutenberg
The Tale of

PETER RABBIT.

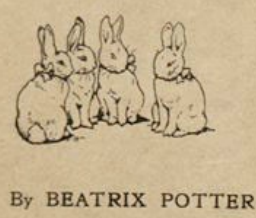
(http://www.gutenberg.org/ebooks/author/292), and you can browse the Beatrix Potter Collections at the Victoria \& Albert Museum in London (http://www.vam.ac.uk/page/b/beatrix-potter/) or in the private collections of rare book dealers (http://www.peterharrington.co.uk/blog/firsteditions-of-peter-rabbit/), but there is something about holding them in your hands. Cover of the first, privately printed edition of The Tale of Peter Rabbit by Beatrix Potter Retrieved from http:// www.abebooks.com/

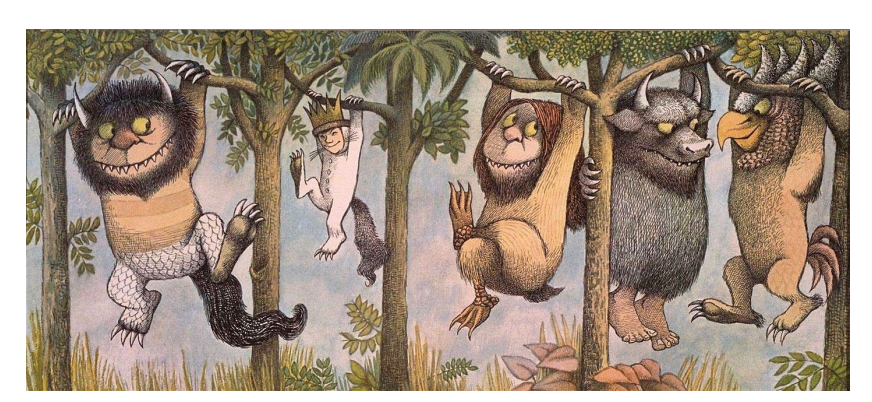

Figure 5.52

Images of Max's "wild rumpus" are immediately recognizable by people across generations. Image from Where the Wild Things Are by Maurice Sendak, 1963, New York, NY: Harper \& Row. Copyright 1963 by Maurice Sendak.

- Real Simple 40 Classic Children's Books Even Adults Love: Definitely includes sentimental favorites

- http://www.realsimple.com/work-life/entertainment/classic-childrens-books

\section{Question \#2: How do we select and apply the appropriate criteria to evaluate books?}

In the previous section, I focused on the author's and illustrator's purpose for creating children's and young adult literature. I also provided a list of genres (categories) that are often found in children's literature. Now that you have a sense of the field, how do you know what's good? 


\section{Elements and Expectations: Overview of the Working Parts}

To determine the effectiveness of the working parts in children's literature, I like to borrow from the experts and use their suggested criteria for choosing award winning children's literature. Yes, awards have issues (see chapter 4), but the award criteria are in our hands now. Again, rather than focus on genres, I prefer to focus on the mode of visual and rhetorical discourse.

When selecting a vehicle (literature) and a particular make and model (genre), the buyer (reader) expects certain standard parts: tires, steering wheel, engine, seats (plot, characters, setting). But then, certain manufacturers/engineers (publishers/authors/ illustrators) tweak the formula to enhance the driving experience: mirrors, cup holders, hands-free systems, music players (innovative design, new media, contemporary topics).

In many cases, what starts off as "optional" can become "standard." Therefore, to evaluate books, consider what comes standard and then look for the manufacturers and engineers (artists and illustrators) who do a better job of making a vehicle with higher levels of design and craft (art and aesthetics of writing and illustrating).

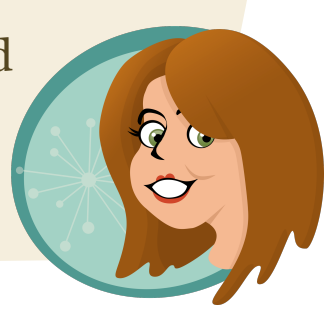

Narration. To evaluate narrative books (i.e., books that tell a story) based primarily on the text, such as contemporary realistic fiction, historical fiction, fantasy, or novels in verse, I use a combination of criteria from the Newbery Medal (http://www.ala.org/alsc/awardsgrants/ bookmedia/newberymedal/newberyterms/newberyterms) and the Printz Award (http://www.ala.org/yalsa/booklistsawards/bookawards/printzaward/aboutprintz/criteria). Depending on the book, one or more of these criteria apply:

- Development of a plot (beginning, middle, end)

- Delineation of characters

- Delineation of a setting

- Distinctive interpretation of the theme or concept

- Excellent presentation of information including accuracy, clarity, and organizational flow

- Appropriateness of style for the audience

- Design and layout of the book 
If the narrative is presented in the form of a picture book or graphic novel, or if it includes sufficient illustration, I use the following criteria from the Caldecott Medal as well (http://www.ala.org/alsc/awardsgrants/bookmedia/caldecottmedal/caldecottterms/caldecottterms).

- Excellence of execution in the artistic technique employed;

- Excellence of pictorial interpretation of story or theme;

- Appropriateness of style of illustration to the story or theme;

- Delineation of plot, theme, characters, setting, mood through the pictures;

- Excellence of presentation in recognition of the intended audience.

Don't expect to find excellence in each of the named elements. The book should, however, have distinguished qualities in all of the elements pertinent to it.

Information. To evaluate nonfiction books based primarily on the text, such as life cycle books, concept books, specialized books, and some biographies, I use a combination of criteria from the Sibert Medal (http://www.ala.org/alsc/awardsgrants/bookmedia/sibertmedal/ sibertterms/sibertmedaltrms) and the Orbis Pictus Award (http://www.ncte.org/awards/orbispictus). Depending on the book, one or more of these criteria will apply:

- Interesting and timely subject matter;

- Excellent, engaging, and distinctive use of language;

- Excellent, engaging, and distinctive use of visuals in illustrated texts (for picture books see below);

- Appropriate organization with clear sequencing and logical development;

- Thorough documentation and author's qualifications;

- Clear, accurate, and stimulating presentation of facts, concepts, and ideas;

- Appropriate style of presentation for subject and for intended audience;

- Supportive features (index, table of contents, maps, timelines, etc.);

- Respectful and of interest to intended audience. 
If the information is presented in the form of a picture book, or if it includes sufficient illustration, I use the following criteria from the Caldecott Medal as well

(http://www.ala.org/alsc/awardsgrants/bookmedia/caldecottmedal/caldecottterms/caldecottterms).

- Excellence of execution in the artistic technique employed;

- Excellence of pictorial interpretation of theme or concept;

- Appropriateness of style of illustration to the theme or concept;

- Delineation of information through the pictures;

- Excellence of presentation in recognition of the intended audience.

Description. To evaluate descriptive books based primarily on the text, such as biography, poetry, journals, and essays, I use a combination of criteria from the NCTE Award for Excellence in Poetry for Children (http://www.ncte.org/awards/poetry), the John Burroughs Riverby Award (American Museum of Natural History, http://research.amnh.org/burroughs/ awards.html), the Newbery Medal (http://www.ala.org/alsc/awardsgrants/bookmedia/newberymedal/ newberyterms/newberyterms) and the Printz Award (http://www.ala.org/yalsa/booklistsawards/ bookawards/printzaward/aboutprintz/criteria). Depending on the book, one or more of these criteria will apply:

- Perceptive and aesthetic accounts of direct experiences in the world;

- Demonstrate authenticity of voice;

- Use of language and form in fresh ways;

- Excellent, engaging, and distinctive use of clear and concise language;

- Excellent, engaging, and distinctive use of vivid language;

- Excellent, engaging and distinctive use of sensory language;

- Appropriate structure to highlight the topic;

- Appropriate organization with clear sequencing and logical development. 
If the description is presented in the form of a picture book, or if it includes sufficient illustration, I use the following criteria from the Caldecott Medal as well

(http://www.ala.org/alsc/awardsgrants/bookmedia/caldecottmedal/caldecottterms/caldecottterms).

- Excellence of execution in the artistic technique employed;

- Excellence of pictorial interpretation of theme or topic;

- Appropriateness of style of illustration to the theme or topic;

- Delineation of description through the pictures;

- Excellence of presentation in recognition of the intended audience.

Argumentation. To evaluate argumentation based primarily on the text, such as historical nonfiction, current nonfiction, and essays, I use a combination of criteria from awards designed to address a point of view or perspective [e.g., Jane Addams Peace Award (http://www.janeaddamspeace.org/jacba/subguide.shtml), Scott O’Dell Award for Historical Fiction (http://www.scottodell.com/pages/scotto'dellawardforhistoricalfiction.aspx), Sibert Medal (http://www.ala.org/alsc/awardsgrants/bookmedia/sibertmedal/sibertterms/sibertmedaltrms) and the Orbis Pictus Award (http://www.ncte.org/awards/orbispictus)].

Depending on the book, one or more of these criteria apply:

- Establishes a central claim;

- Provides clear and accurate evidence to support the claim;

- Appropriate organization with clear sequencing and logical development;

- Appropriate style of presentation for subject and for intended audience;

- Consistency and coherence within the chain of reasoning;

- Honest and intimate accounts of experience that are relevant. 
If the argumentation is presented in the form of a picture book, or if it includes sufficient illustration, I use the following criteria from the Caldecott Medal as well (http://www.ala.org/ alsc/awardsgrants/bookmedia/caldecottmedal/caldecottterms/caldecottterms).

- Excellence of execution in the artistic technique employed;

- Excellence of pictorial interpretation of theme or argument;

- Appropriateness of style of illustration to the theme or argument;

- Delineation of argument through the pictures;

- Excellence of presentation in recognition of the intended audience.

Although I selected these criteria to evaluate quality in children's literature, your use of criteria will be subjective. Rather than attempting to seek inter-rater reliability, the purpose of sharing the criteria is to help you see the books differently.

For example, many people love the books, Guess How Much I Love You (McBrantney, 1995) or Love You Forever (Munsch, 1986). These books are popular and people buy them when they have babies or young children at home. If you view the books from the warm and wonderful experience of being read to as a child, then you will value them. However, if you consider text structures, authorial intent, rhetorical moves, and cultural implications, you will understand why children may not be interested in reading this book on their own without parent initiation. You might also understand how others might critique the book.

Children's literature, while seemingly innocent and simple to those unfamiliar with its depth and scope, can provide the opportunity for deep structural analysis and cultural criticism.

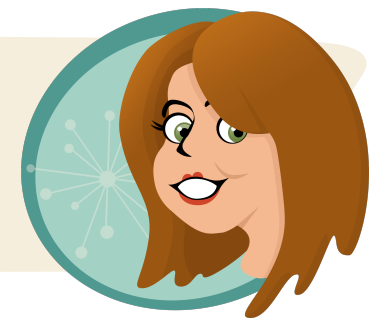




\section{Question \#3: How do we match books to readers?}

\section{Reading Development and the Role of Children's Literature}

Reading interests vary person to person. In the US, there is a cultural tendency to divide children and youth by gender. But gender is an arbitrary category and reading interests are more complicated than gender assignment. There aren't "girl" books or "boy" books. There are books. Girls read books about boys (Harry Potter) and boys read books about girls (Hunger Games). Girls read genres typically associated with boys such as fantasy, science information books, and graphic novels. Boys read genres typically associated with girls such as poetry, fiction, and biographies. That is-if people (parents, teachers, librarians, friends, siblings, booksellers, media and television personalities, filmmakers, and social networks) let them read what they want. In fact, the individuality of book choice becomes even more pronounced if youth are encouraged to pursue their interests.

Hey, this is important. When you go to McDonalds and order a happy meal, there aren't girl toys and boy toys. There are toys. Just let the kids pick the toy.

There aren't girl colors and boy colors. Colors are colors. We are constructing gendered notions of color.

If you don't believe me, then believe the Smithsonian:

http://www.smithsonianmag.com/arts-culture/when-did-girls-start-wearingpink-1370097/?no-ist

Or NPR: http://www.npr.org/2014/04/01/297159948/girls-are-taught-to-think-pink-butthat-wasnt-always-so

Or the BBC: http://www.bbc.com/future/story/20141117-the-pink-vs-blue-gender-myth Why do we do such a thing?

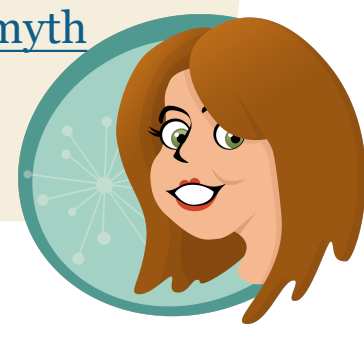


Shaming and shunning have been used as a form of public humiliation for centuries. Today, many criminal courts use shaming instead of incarceration or financial penalties. Shaming is a form of social control, which is precisely why gay-shaming and fat-shaming are forms of bullying.

Read more about shaming as a form of public humiliation:

http://www.latimes.com/opinion/op-ed/la-oe-0525-morrison-sentencing-shamejudges-20140525-column.html

http://www.npr.org/2013/08/24/215097279/some-judges-prefer-public-shamingto-prison

http://www.slate.com/articles/news_and_politics/view_from_chicago/2015/04/ internet_shaming_the_legal_history_of_shame_and_its_costs_and_benefits.html

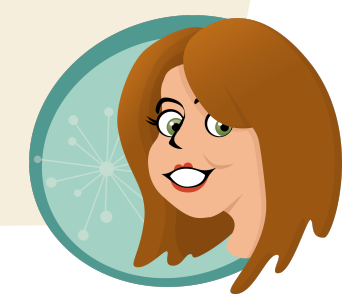

Along the same lines, shaming has no place in children's literature selection. Public ridicule for a child's book preference (or toy or color preference, for that matter) is not appropriate. Book choices are personal preferences, not punishable offenses. My book preferences are not indicative of my sexual, social, gender, or professional identities, nor do my reading preferences alter my behavior. Just because I read about someone's heroin addiction doesn't mean I will become addicted to heroin (or want to try heroin, or even know where to buy it or what to do with it.) But reading about a character with a heroin addiction will help me understand someone else's perspective and experiences as I think about my own.

Alternatively, if someone with different life experiences and different tendencies toward drug use reads about heroin addiction, he or she may have a different personal reaction than me. However, there are many people and intervening events between books and the real, live people who read them. Books are mirrors, and windows, and maps!

"Book choices are personal preferences, not punishable offenses."

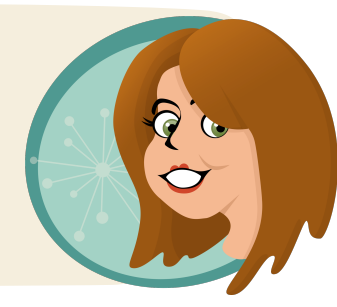


With an understanding that idiosyncratic factors are at play in the determination of book preferences, we can examine reading trends and develop strategies for selecting books based on developmental considerations for youth. Please remember, these are generic recommendations based on broad patterns of physical, cognitive, and social development (Video 5.4). The only way to know what a particular child will read is to ask the child, offer different types of books, and encourage reading. Plus, you have to pay attention and look and listen very carefully.

\section{READING DEVELOPMENT AND SELECTING TEXTS FOR CHILDREN:} BIRTH TO ADOLESCENCE

\section{WITH JENIFER SCHNEIDER}

\section{THE INSIDE, OUTSIDE, AND UPSIDE DOWNS $\mid$ From Poets and Pop-ups to Princesses OF CHLLDREN'S LITERATURE}




\section{Babies}

"Babies can't read." This statement is true only if you have a very formal, school-based conception of reading. Babies don't go to school or sit at desks; therefore, don't expect them to read the same way a 6-year-old reads (Figure 5.53). Instead, newborn babies experience reading (Video 5.5).

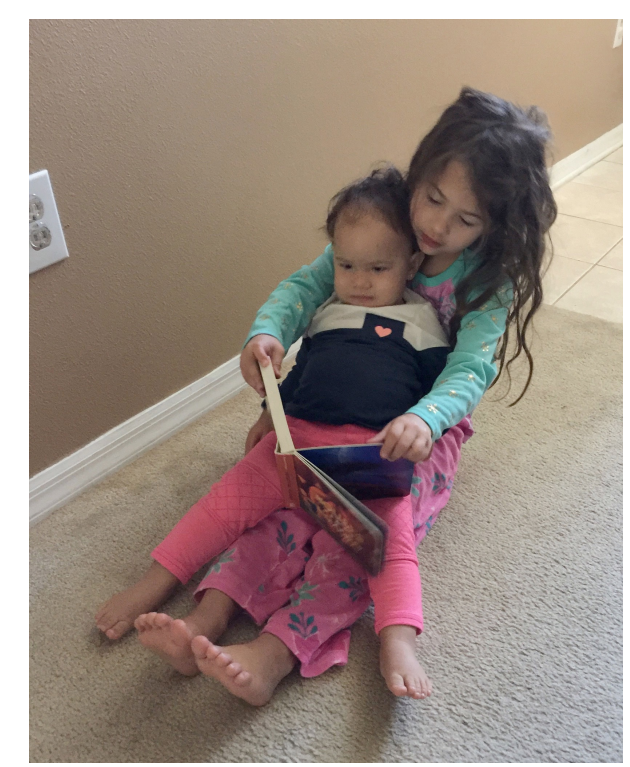

Figure 5.53

Babies read differently than older children. Photo copyright 2015 by Aimee Frier.

Books are expensive. Here is an idea. I had a book shower when my daughter was born. I registered for books on Amazon and received books as gifts. Diapers get dirty. Books last a lifetime.

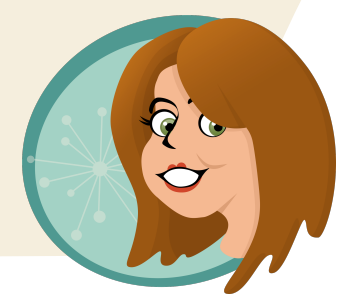

Video 5.5 Reading to a Newborn http://www.kaltura.com/tiny/m3fdp

\section{READING TO A NEWBORN 2 MONTHS OLD}

WITH JENIFER SCHNEIDER

\section{THE INSIDE, OUTSIDE, AND UPSIDE DOWNS $\mid$ From Poets and Pop-ups to Princesses OF CHILDREN'S LITERATURE and Porridge}


Babies exhibit emergent reading behaviors when they have access to books. In other words, little babies read with their eyes, their hands, and their body language (Figure 5.54). Older babies learn how to hold books, turn the pages, and follow along (Figure 5.55). Parents, family members, teachers, and caregivers who recognize and encourage these behaviors (Figure 5.56) can significantly effect a child's attitude toward reading, can help a child develop the persistence necessary to be receptive to later reading instruction, can help a child develop higher-level thinking skills, can increase a child's language proficiency, and can help a child acquire basic academic knowledge (Gregory and Morrison, 1998; High et.al., 2014).

The key figure in baby reading is the adult who recognizes early reading behaviors and encourages them, not discourages them (Video 5.6).

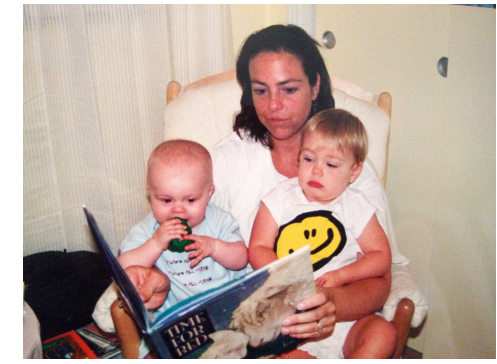

Figure 5.54

Babies read with their eyes. Photo copyright 2000 by Jenifer Schneider.

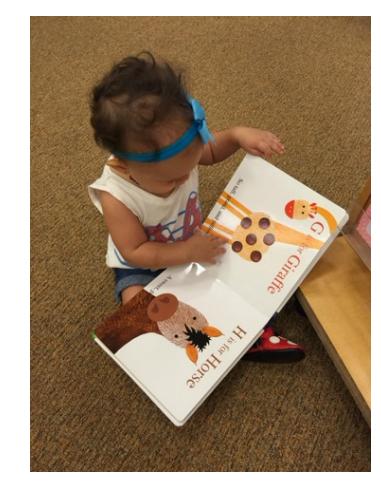

Figure 5.55

Babies exhibit emergent reading behaviors when they have access to books. They learn how to hold books, turn the pages, and follow along. Photo copyright 2015 by Aimee Frier.

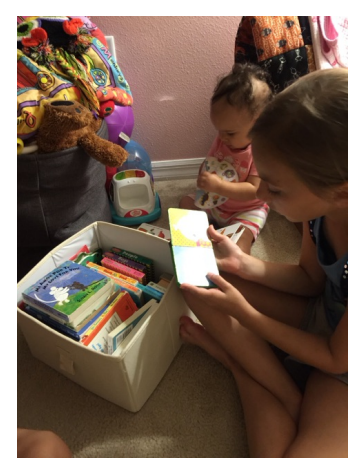

Figure 5.56

Family members, including older siblings and cousins, who recognize and encourage reading behaviors can significantly affect a child's attitude toward reading. Photo copyright 2015 by Aimee Frier.

I'm reminded of a quote: "Children are made readers on the laps of their parents." - Emilie Buchwald

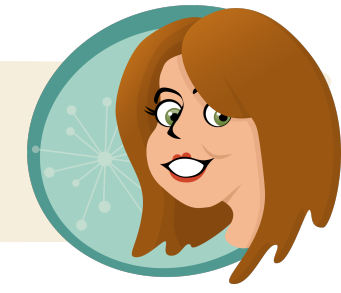

Video 5.6 Reading to a Baby http://www.kaltura.com/tiny/ol2hj

\section{PEADING TO A BABY 9MONTHS OLD}


Babies will gnaw on books. That's ok; babies explore the world with their mouths. That's why publishers make baby books. As a parent, I used all forms of baby books, depending on where I was going.

\section{Short List of Recommendations for Babies:}

- Soft books for teething time. Soft books are great for quiet places like church or doctor's waiting rooms. Soft books work well for the car seat or in restaurants (Figure 5.57). On a personal note, I loved soft books because my older daughter spit up a lot. Soft books are washable!

- Waterproof books for bath time (also good for the babies who spit up a lot). But they will get moldy inside, so squeeze and sniff for smelly funk.

- Touch and feel books for bedtime.

- Board books for the stroller.

- Baby books are great because they are small, the pictures and text match, the images are clear, and babies can hold them.

- Sandra Boynton has wonderful board books (Figure 5.58).

- I love anything with Sesame Street characters. Sesame Street publishes lots of board books.

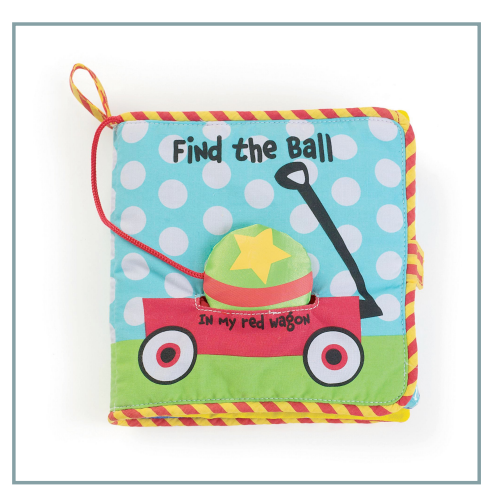

Figure 5.57

Soft books work well for many reasons. Babies can read, chew, or throw them. Find the Ball by Manhattan Toy, nd, Minneapolis, MN. Copyright 2015 by Manhattan Toy Company.

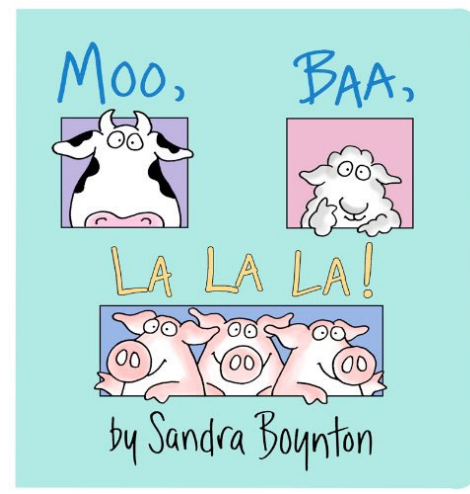

Figure 5.58

Sandra Boynton has collections of board books that feature simple illustrations and funny, rhythmic, and repetitive text. Moo, Baa, La La La by Sandra Boynton, 1982, New York, NY: Little Simon. Copyright 1982 by Sandra Boynton.

- But babies also need bigger books with more elaborate language and pictures. It's ok if the babies can't "read" them. They will "read" them in their own way by looking, touching, and licking.

- When babies are read to, and someone turns the pages and guides their attention, babies will learn to look at the pictures, follow the pages, and hear the language (which is different than talking). 
Warning for parents! Babies are captive. They can't wiggle off a lap and walk away. So parents and caregivers should create the habit of reading while a baby can't bolt. Also, there isn't much "reward" in reading to a newborn baby. Hang in there. Read whatever you like-just keep reading. Make reading a routine (Bath, Bottle, Book, Bed). When you feed a baby, read to a baby.

\section{Bath, Bottle, Book, Bed- \\ When you feed a baby, read to a baby.}

Suggestions for others: If you feed a baby, read to a baby. In other words, if you work in industries that deal with food, food products, or baby products (e.g., infant formula development, engineering baby products, grocery stores, food banks, homeless shelters, social work, healthcare), keep this motto in mind. How could your business or industry educate families about the importance of baby books?

\section{Toddlers}

As babies grow into toddlers, they will develop a general sense of how books work if they see how books work. That is, they learn that books are read from front to back, top to bottom, and left to right. Adults have to show them how (Video 5.7).

Kids don't learn to read by osmosis. Remember, reading is a human creation. Book reading is shaped, just like talking and walking.

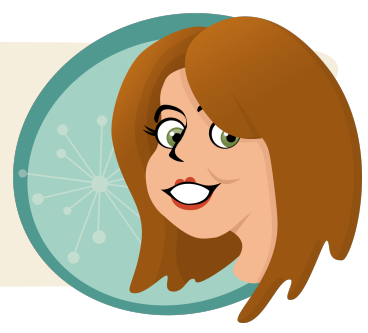


Video 5.7 Reading with a Toddler http://www.kaltura.com/tiny/mg2he

\section{READING WITH A TODDLER 16 MONTHS OLD}

\section{WITH JENIFER SCHNEIDER}

\section{THE INSIDE, OUTSIDE, AND UPSIDE DOWNS $\quad$ From Poets and Pop-ups to Princesses OF CHILDREN'S LITERATURE and Porridge}

When toddlers read books with their parents, they learn that squiggly black lines (text) carry the messages on each page, telling the reader what to say. It's an amazing phenomenon to toddlers, and they will ask for the same book over and over and over again. When children ask for the same book, just read it. I know it's annoying, but get over it. Here's why.

You exhibit the same annoying behavior when you incessantly listen to your favorite songs or watch reruns of your favorite shows.

- If adults read the same book over and over again, toddlers learn that the message stays exactly the same every single time. In other words, print has lasting power.

Think about how comforting that may seem to a toddler. In a world full of information and different experiences every day, sameness and routine are comforting.

- When a toddler hears the same book over and over again, he or she is matching the spoken words to the text. The child will start to remember the story and the words.

This is when many parents will say, "She's not really reading."

Trust me, she is reading. When she says dada, she's talking, right?

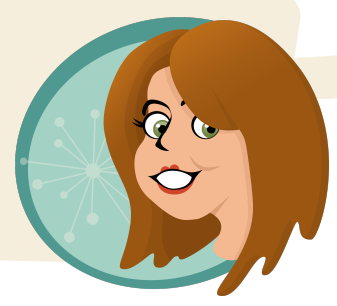


- Reading the same book helps the child gain a sense of story and begin to understand the structure of the rhetorical presentation (depending on the book's purpose).

- The child is making predictions and watching them come true, over and over again. The child is feeling smart. This is rewarding, motivating, and enjoyable-all things needed for a child to become a reader.

\section{Short List of Recommendations for Toddlers:}

- Dr. Seuss' Beginner Books Series is fantastic. The stories are clever. The language is predictable in some books. In fact, many of Dr. Seuss' beginner books were written with the same 100 words to facilitate children's learning (Figure 5.59).

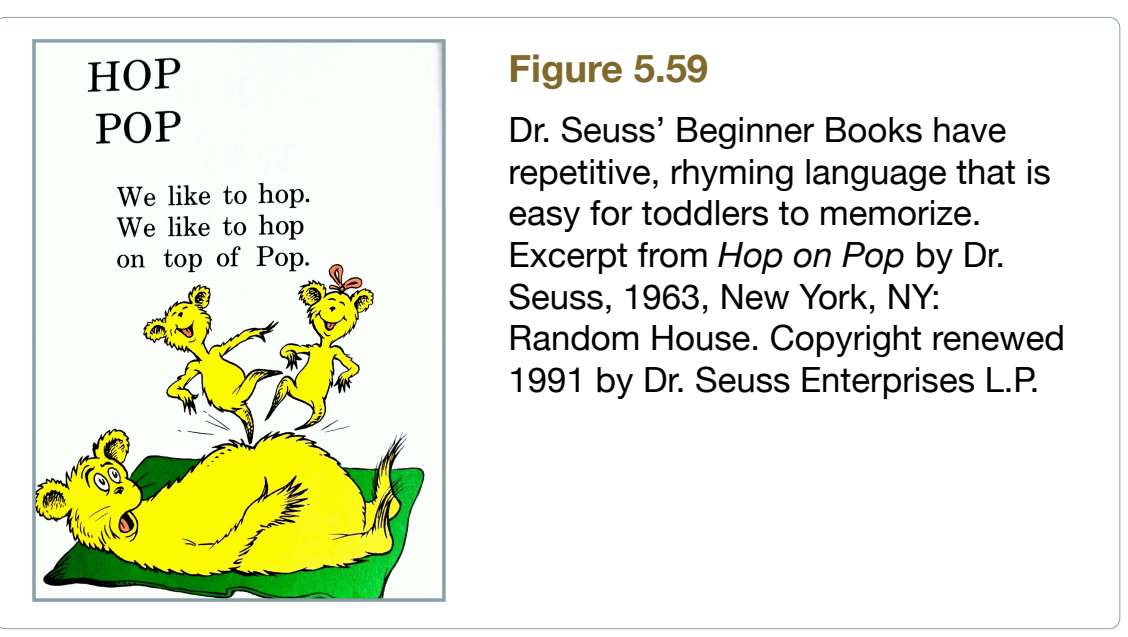

Some people don't like the Berenstain Bears. I do. They are the book version of TV sitcoms-goofy characters and repetitive plots.

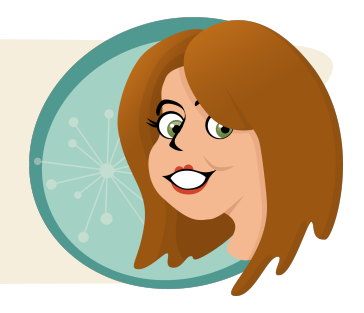

- The Berenstain Bears books are also excellent for toddlers with simple phrases, rhymes, and repetition.

Rhyming books are perfect for toddlers. The rhythm and rhyme will help children remember the words; and remembering is a sign of reading.

Remembering is a sign of reading.

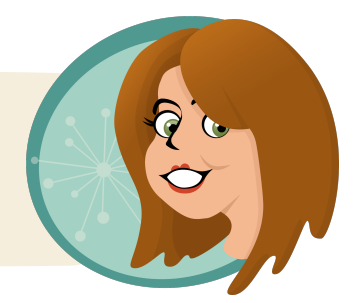

- Interactive books are important as well. I'm not talking about elaborate pop-ups, but peek-a-boo type books create suspense and playfulness around reading.

- I love anything with Sesame Street characters for this age as well. I think Sesame Street does a great job with their books (Figure 5.60).

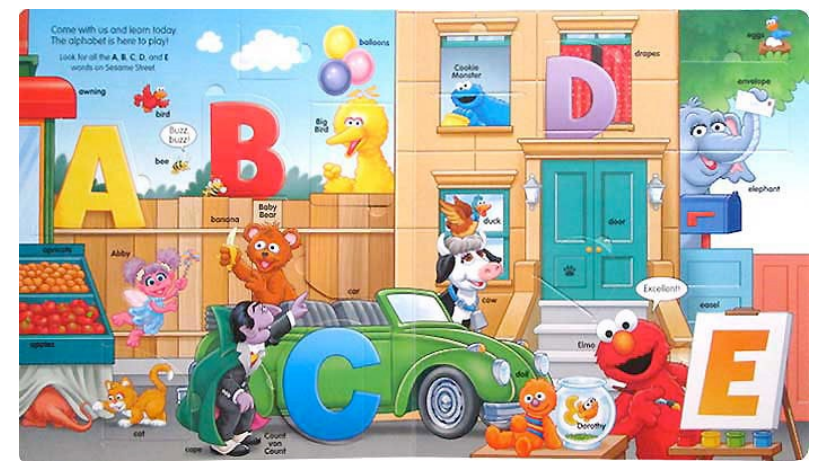

Figure 5.60

Elmo is a favorite, recognizable character. This lift the flap book features letters, characters, and labels. Sesame Street: Elmo's ABC Lift-the-Flap by Sesame Street, 2014, New York, NY: Reader's Digest. Copyright 2014 by Sesame Street. 
Warning for parents! Toddlers are not captive. They will wiggle off a lap and run away. It's ok. Don't take it personally. And don't give up. Don't ever give up! One minute of reading is better than no minutes. Make book reading enjoyable. Choose books that the child will love. But also choose books that you love. Make reading a routine (Bath, Brush (teeth), Book, Bed). If the child won't sit on your lap, then read the book aloud in the same room where he or she can hear you while playing. Read the book to another family member. Do anything to draw attention to the importance and enjoyment of the event.

\section{Make a reading routine (Bath, Brush (teeth), Book, Bed).}

I'm not above bribery. "Hey, do you want to have some cookies when we read our book tonight?" Make it Bath, Biscuit, Brush, Book, Bed!

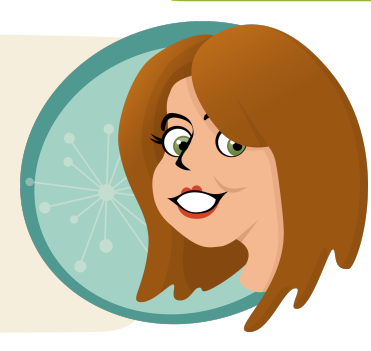

Suggestions for others: Toddlers do not sit still. They need to move. How could your business or industry incorporate movement into literacy events? For example, many malls have play spaces for young children, but I haven't seen any with books. If you work in industries that deal with toys, children's programming, or educational products, is there a place for books, play, and movement? 


\section{Young Children}

Young children can exhibit many of the same preferences and behaviors as toddlers (Video 5.8). They may wiggle away and prefer to play rather than read. They may enjoy reading books over and over again or they may like reading a different book each day.

If a child is 5 or 6 and raised in a home of daily reading, the parents have read aloud approximately 2000 times. It gets old. If you are responsible for reading to young children, read books that you like. Enthusiasm for reading is as important as the quality of the text. Don't give up!

And if you are a parent and you gave up, start again. It's never too late.

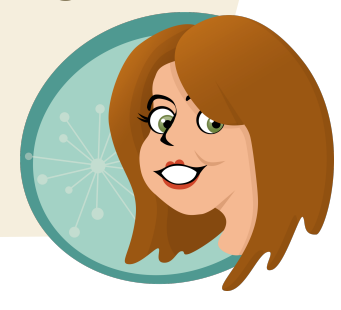

Video 5.8 Reading with Young Children http://www.kaltura.com/tiny/k4ktd

\section{READING WITH YOUNG CHILDREN 2 AND 3 YEARS OLD}

\section{WITH JENIFER SCHNEIDER}

\section{THE INSIDE, OUTSIDE, AND UPSIDE DOWNS $\mid$ From Poets and Pop-ups to Princesses OF CHILDREN'S LITERATURE $\quad$ and Porridge}

The best thing to do for young children is to vary the selection of books to get their attention. Alternatively, you may have to read the same book over and over to get their attention. 


\section{Short List of Recommendations for Young Children:}

- Predictable books with a strong picture and text match are ideal for young children. Books from Eric Carle, Donald Crews, Molly Bang, and Lois Ehlert are excellent choices.

- Many Dr. Seuss books are elaborate with detailed stories (e.g., Horton Hears a Who; The Lorax). Toddlers can't sit still through a long Dr. Seuss book, but young children can. The language is interesting and some of the vocabulary is made up. When you come across funny words, play with the pronunciation and tone.

- I like funny books. So do young children. Check out the books on the Sid Fleishman Humor Award list. http://www.scbwi.org/awards/sid-fleischman-award/.

- The Ted Geisel Award is given to books that are perfectly suited for young, emergent readers. http://www.ala.org/alsc/awardsgrants/bookmedia/geiselaward

- Anything by Maurice Sendak. Wild Things. Enough said.

- Some classics include:

○ Arnold Lobel-Frog and Toad;

- Richard Scarry-Busy books (Figure 5.61);

○ Rosemary Wells-Max and Ruby, Sophie, Yoko, Nora.

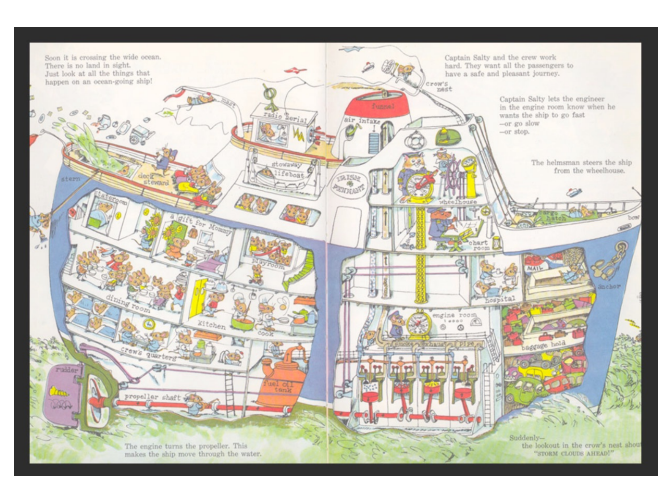

Figure 5.61

I loved Richard Scarry as a child. His illustrations were intricate with hidden sub-plots. Excerpt from What Do People Do All Day? by Richard Scarry, 1968, New York, NY: Random House. Copyright 1968 by Richard Scarry.

- I also love anything by Mo Willems for this age group. He is funny for kids and funny for adults. He used to work for Sesame Street and he really knows how to write for young children and their grown-ups.

- Henry Cole and Doreen Cronin are also excellent picture book creators for this age group.

- Picture books come in all shapes and sizes. Check out pop-up books. Young children can visit the library and check out several at a time. It's great to have variety. 
Warning for parents! Early reading is not a sign of giftedness. Late reading is not a sign of developmental delays. I used to teach first grade. I have two children of my own. I've been a literacy professor for almost 20 years. I promise-early readers are not necessarily gifted. Early readers are children with book experience. Now, that's not to say that lots of exposure to books and having conversations about the content isn't an intervening factor in a student's success. It most certainly is. But do not fret if your child is a late reader. Also, don't call Harvard if your child is reading at the age of 2 or 3 . Early reading gives a child an advantage with the start of school, but many other factors come into play along the way.

Suggestions for others: Programs like Accelerated Reader, which level books and administer computerized tests, claim to be effective; but research indicates that external motivators can have a negative impact (Cox, 2012; Huang, 2012 Schaffner, Schiefele, \& Ulferts, 2013). Asking students to take a test after every book is not fun. In fact, it's counter to the purposes of reading. Assigning a reading level and telling kids to read books that are coded to that level, is also demotivating. Books should be selected based on children's interests. Competing with others to read more books? That works for a very small minority of highly competitive people. Plus, those of you with knowledge of psychology know that competition is no way to motivate a reader. If you work in computer programming or product development, keep developmental issues in mind when your company develops software. Reading isn't a race.

On Lexiles and reading competitions: I know, you competitive types disagree. But remember, not everyone is like you. Why in the world would anyone read to earn dots, jelly beans, or pizzas. It makes no sense. There is no immediate reward. Also, how do jelly beans, dots, and awards connect to the author's or illustrator's purpose for creating the book? They don't.

Teachers, the world is full of people who say that the only thing that got them (or their child) reading was Captain Underpants or Harry Potter. They recall books with memorable characters, funny or moving plotlines, and shared experiences with friends. I have yet to hear any adult recall fond memories of books with dots and Lexiles (https://lexile.com/). That's a teacher thing; not a reader thing. Please, know the difference. Yes, you need to find a kid's reading level to provide instruction that isn't too hard or too easy, but don't let Lexiles and levels undermine the benefits of reading choice. If a kid knows his or her Lexile, but hates reading, YOU get an F-.

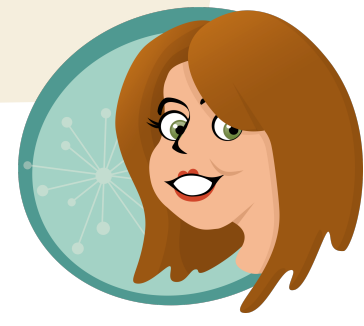




\section{Older Children}

Once children can read on their own, parents and teachers often abandon the read aloud routine. Parenting is exhausting and relentless. Adults have so many other things to do. But reading aloud is essential throughout a child's developmental years.

My daughters laugh about the times when I fell asleep mid-sentence. Or when they were annoyed because I read the same sentence over and over again (because I was sleepy). And they don't even know about the times when I chose to read the shortest book on the shelf. I get it. You don't have to be perfect. Just don't give up.

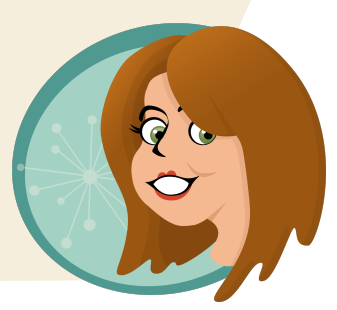

Here's why. Reading time can be bonding time. Books allow parents to discuss topics that may not come up during the regular normal routine (Video 5.9). The same is true for teachers during the school day.

Reading aloud offers children exposure to many different books and linguistic styles. If parents or teachers read aloud books on topics of their choice, then the child will be exposed to those books.

Children can comprehend a larger vocabulary than what they can produce. When children are read to, adults expose them to new words and concepts they won't get on their own.

Video 5.9 Reading with Young Children http://www.kaltura.com/tiny/ng9aq

\section{READING WITH OLDER CHILDREN 7 AND 9 YEARS OLD}

\section{WITH JENIFER SCHNEIDER}


Parents also use book reading to introduce children to cultural connections and they reinforce language learning.

In addition, older children like to read about people and places that are different from their own lives. They especially enjoy topics that are interesting, scary, and often inappropriate in the eyes of parents and teachers. I say, let them read. Let them read what they want. Let them read above and below their reading "level." Let them read how they want, where they want, and when they want.

\section{Short List of Recommendations for Older Children:}

- Older children will venture out to find their own preferences. Most kids love book series like Diary of a Wimpy Kid by Jeff Kinney or Captain Underpants by Dav Pilkey.

- Picture books are not only acceptable, they are encouraged! Older readers should certainly continue to read picture books. Good choices are anything by Jon Scieszka and Lane Smith, Chris Van Allsburg (Figure 5.62), and Patricia Pollacco.

- You might see a spike in information book reading in older children. Kids like to learn about the world. This is the age
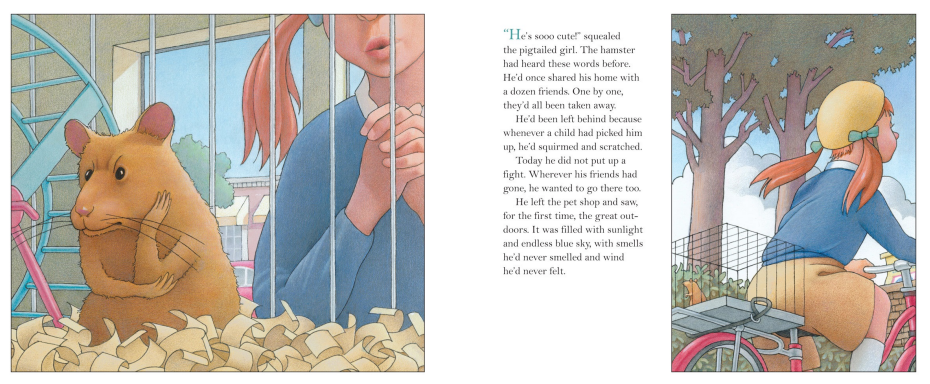

Figure 5.62

Most of you might remember The Wreck of the Zephyr or The $Z$ was Zapped, but Chris Van Allsburg has new books too. The Misadventures of Sweetie Pie by Chris Van Allsburg, 2014, New York, NY: HMH Books for Young Readers. Copyright 2014 by Chris Van Allsburg. where obsessions begin to develop-horses, video games, sports, dogs, cats, music, etc. Go with it. You might even try reading some aloud. Imagine what your kids would think if you read about farts.

- Graphic novels are excellent forms of literature for all children.

- Many children like to read stories about urban youth. Authors like G. Neri, and Jacqueline Woodson (Figure 5.63) create modern, relevant books for a variety of readers.

- Older children also enjoy series books. This is the age to start reading Harry Potter.

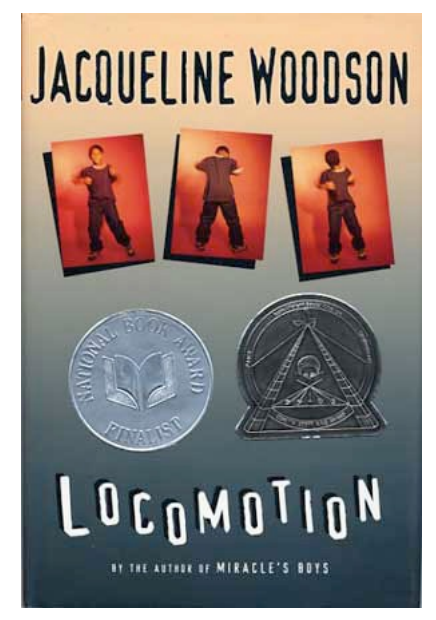

Figure 5.63

Jacqueline Woodson writes about Lonnie, a boy in foster care who finds hope through poetry. Locomotion by Jacqueline Woodson, 2003, New York, NY: G.P. Putnam \& Sons. Copyright 2003 by Jacqueline Woodson.

- This is also the age to start learning about the world through a more critical lens. Books by Lois Lowry and Katherine Paterson will provide exposure to a broad range of topics through excellent stories and beautiful writing. 
Warning for Parents! This is the age when children encounter intervening effects of school-good and bad teachers, good and bad friends, good and bad books, good and bad reading habits. I see nothing wrong with "bad" books, but you have to make the call for your own child (see banned books chapter.) You will have to make the call on the good and bad friends as well. Here are a few strategies to support young adolescents' reading habits.

- Barter tech time for reading time. In other words, if they read $x$ minutes, then they get $x$ minutes to game, chat, text or whatever.

- Alternate reading aloud. Older kids start to play sports, join clubs, and have social lives. You might find it difficult to read aloud every night so alternate reading aloud with reading on their own.

- Get audiobooks for the car. If you commute to school or sports, play audiobooks. OK, so they aren't "reading" the text, but they are hearing the stories or information. When you know books, you make more connections.

Suggestions for others: Unlike books for babies or toddlers, older children know how books work and they take care of them for the most part. Therefore, books can be "littered" in many spaces beyond a library and bookstore. I think it's an incredible waste of opportunity when I visit doctors' and dentists' offices and there aren't any books for kids. There are many spaces in which books could replace televisions. Can you think of any? If not, use some ideas from Little Free Library (http://littlefreelibrary.org).

My children's dentist is an exception (Figure 5.64).

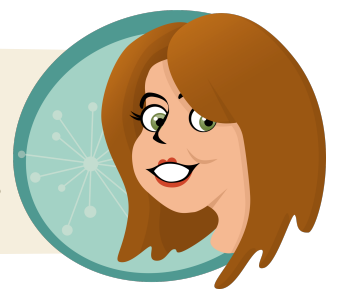

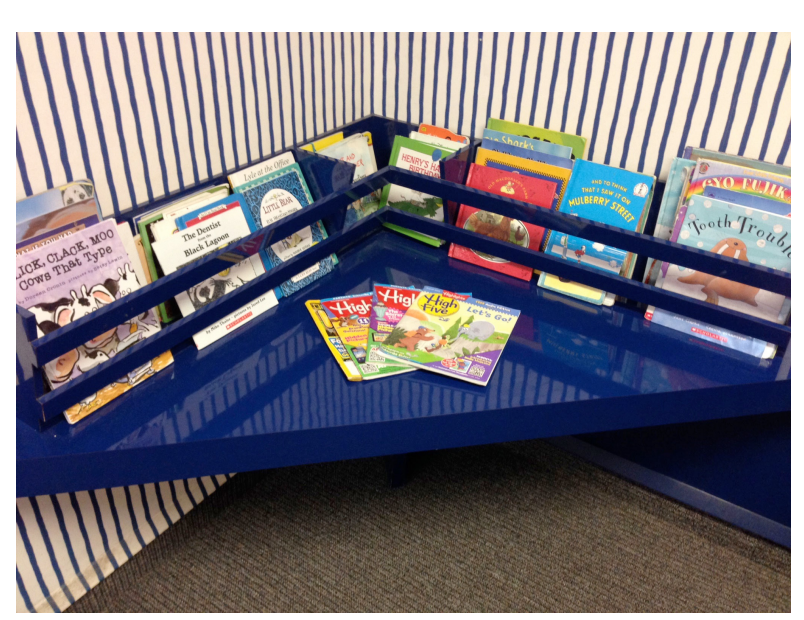

Figure 5.64

My daughters' dentist, Dr. Gerald Copeland, is an exception - his office has a large selection of books for children of all ages. He also has an extensive array of interesting magazines of all types. He invests in his patients' literacy and he is thoughtful about parent, child, and teen wait time. Photo copyright 2015 by Jenifer Schneider. 


\section{Young Adults}

Young adults have varied interests. They read across many genres including biography, history, military history, science, mythology, video games, celebrities, current events, fan fiction, realistic fiction, outdoor, TV shows, and teens (Moeller \& Becnel, 2015).

In good schools, with enterprising teachers, students are encouraged to join book clubs and other forums for reading and sharing literature. I know one AP English teacher, in a public high school, who created an LGBT Book Club during lunch. All students in the school were invited and about 30 students showed up to talk about books. Why can't parents have book clubs at home?

I try to read the same books as my children so we can talk about them.

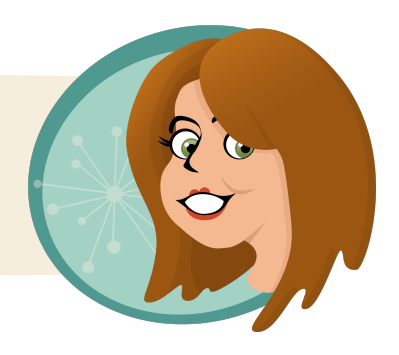

A popular genre for teens is urban literature or street lit. Different than multicultural literature which often depicts characters of color in a variety of settings, urban or street literature is set in lower-income, city neighborhoods (Morris, 2012). Organizations such as Kids Like Us (http://www.kidslikeus.org) and Street Literature (http://www.streetliterature.com/) promote urban literature for children in city schools. Young adults from all backgrounds enjoy reading street lit.

I never read Treasure Island as a kid. But when my daughter read it in 7 th grade, she asked me to read it so we could talk about it!

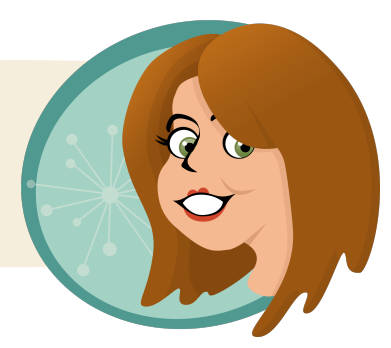

In the young adult years, books can serve as a social conduit, bringing teens and adults together. Young adults also engage with authors and illustrators through social networking and fan clubs. Another hallmark of young adults is an interest in fanfiction. 


\section{Short List of Recommendations for Young Adults:}

- Young adults love edgy, authentic writing. Some of their favorite authors are:

๑ John Green

○ Neil Gaiman

○ J.K. Rowling

○ Philip Pullman (Figure 5.65)

- Cassandra Clare

○ Susan Cooper

○ Lauren Oliver

- Also, young adults are still reading the same books you read in high school. If there are books you loved, there are kids who will read them today.

○ The Outsiders by S.E. Hinton

○ Treasure Island by Robert Louis Stevenson

- The Chocolate War by Robert Cormier

○ The Hobbit/The Lord of the Rings trilogy by J.R.R. Tolkien

○ The Princess Diaries by Meg Cabot

- Many picture books are targeted at young adults. Intricate picture books, along with graphic novels, combine art and text. Don't think about picture books as baby books. Think of them as fine art coupled with short stories or graphic representations of current information.
Figure 5.65

Edgy and authentic are two words that describe Philip Pullman's books. For example, His Dark Materials are best selling books that continue to be read by new generations. The 20th anniversary edition of Northern Lights was published in 2015. Northern Lights (His Dark Materials) by Philip Pullman, 1995, London, England: Scholastic UK. Copyright 1995 by Philip Pullman. 
Warning for parents! Stay open to changes in expertise. When children are young, parents guide their choices in books. When children reach middle and high school, they get recommendations from friends, teachers, librarians, social networks, and websites. Maintain literary connections with children-even when they are grown.

Also, as children develop into young adults, many people assume they don't read paper copies of books because young adults read on the computer or on e-reader devices. Young adults read on the computer or on e-reader devices. This is true for many, but not for all. Many young adults continue to prefer paper-bound books.

Suggestions for others: As mentioned above, doctors' and dentists' offices tend to provide limited numbers and poor quality books for children to read. But when it comes to young adults, they are completely ignored! When was the last time you saw young adult reading material in a waiting room, airport, or train station? Newspapers and magazines are prevalent, but how about thinking outside the box? Young adults have more sophisticated reading tastes, but they don't have time to complete a novel during a doctor's visit. Alternative reading sources include graphic novels, manga and anime, and elaborate information books. If you work in a business or industry where people wait, linger, or shop, consider young adults' interests.

\section{Book Recommendation Services}

There is a lot to consider when choosing a book for a reader. If it feels overwhelming, you can always go the computer-programming route and have an algorithm choose a book for you. Just like vehicle recommender programs and dog matching quizzes, there are book recommender services that take into account several factors such as the reader's age, interests, favorite books, etc. Unlike data analytics software, such as the programs used by Amazon, other reader programs use the information you provide rather than previous purchase data. On the surface, the idea seems better suited to book selection practices since the user (reader) provides the information. For example, Amazon often gives me false results because I don't necessarily like every book I buy and I don't always look for books I want. However, many of the recommendation services target adults and the book information is only as accurate as the person who read and coded the keywords to describe the book. 
In any case, here are a few book selection sites:

- Whichbook (http://www.openingthebook.com/whichbook/)

- What Should I Read Next? (http://www.whatshouldireadnext.com/)

- Your Next Read (http://www.yournextread.com/us/)

Recommendation Services are Internet dating sites for book selection.

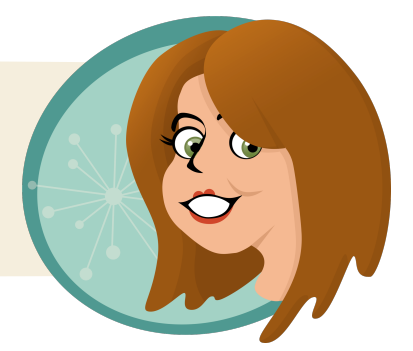

\section{Question \#4: How do we judge the overall product to know what works?}

At the beginning of this chapter, I discussed the modes of discourse in children's literature and I reviewed criteria to analyze particular texts. Then I discussed the impact of family literacy events and emphasized the type, quality, and quantity of experiences a child can have with books. Now, let's get back to the books.

\section{Know Your Criteria: Comparison Shop}

Choosing books is like buying a car: some of it's rigged (by publishers), some of it's luck, and everyone is happy if there's a match. First, in choosing books, your priority must be the reader. Your priorities and interpretation of the criteria will change depending on whether you are you selecting books for yourself, or a toddler, or a 9th grader. Second, you have to know the books. Do some research and become familiar with books. Read-a lot! Third, make a guess. Of course it's not a shot in the dark. Your guess is based on knowledge.

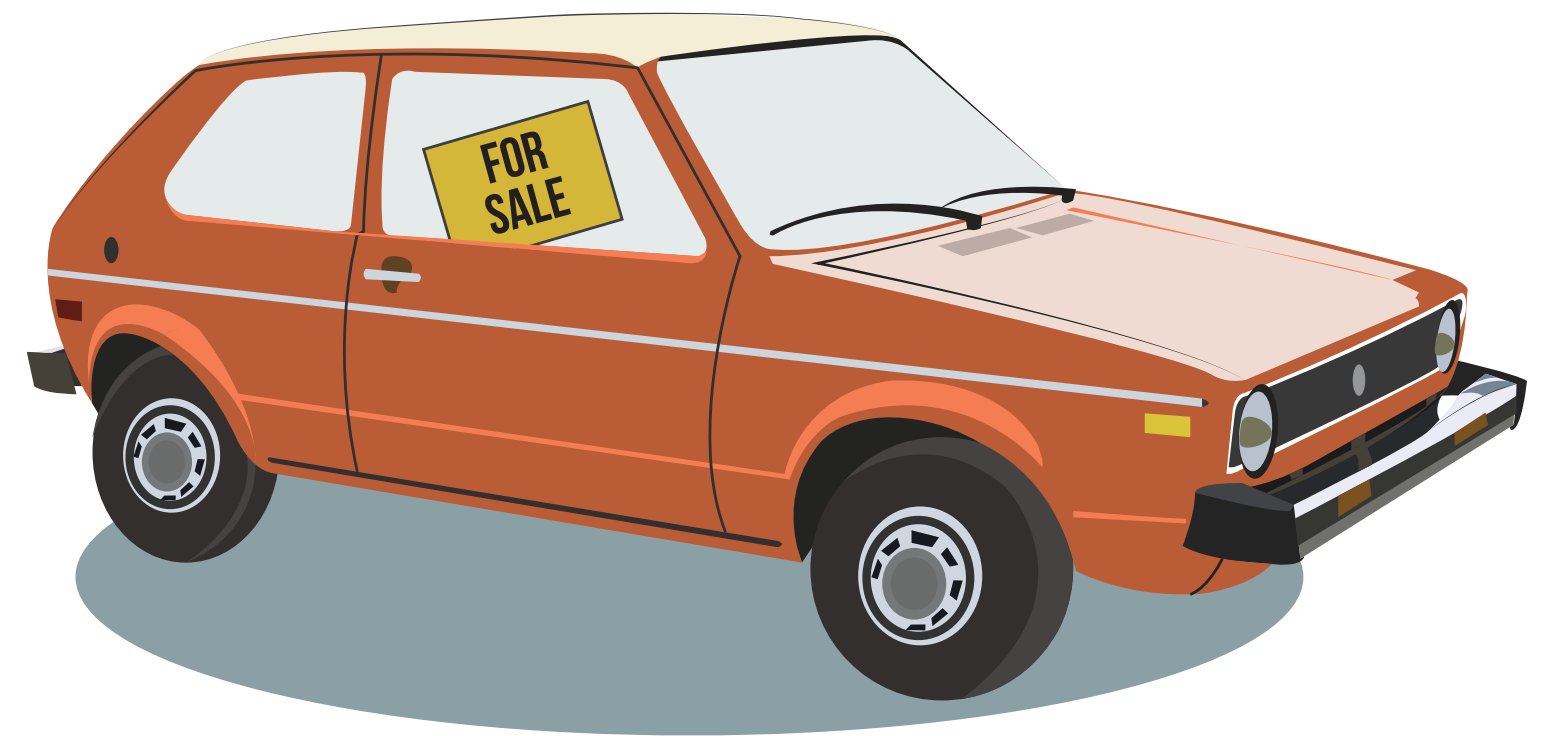




\section{Preview the Book: Take a Test Drive and Don't Fall for Gimmicks}

The "match" extends beyond the child and the books. You have to consider the family as well. Will the parents support the book purchase? Will parents be the primary readers or will they object to the content? Drew Magary (2012) wrote a funny article with advice for parents about reading books to kids. He offered 10 tips for avoiding terrible books. You should read the whole article for his commentary (if you don't mind a lot of cursing). Here's a nutshell version of his advice:

1. Check for length and textual density. Long books are "medieval torture devices."

2. Make sure the text rhymes. Rhyming is more fun.

3. Avoid one-trick ponies. Too formulaic.

4. Avoid repetitive books. Too annoying.

5. Do not buy fancy pop-up books. Too tedious.

6. Buy any book that features textures (e.g. Pat the Bunny). Fun and quick.

7. Do not buy any Amelia Bedelia books. She's too stupid.

8. NEVER buy a DK reader book. Written by a "corporate spambot."

9. Never buy any book that's a movie or TV tie-in. It's like buying an advertisement.

10. Never buy a children's book written by a celebrity. Epic fails.

Of course I don't agree with everything listed, but Magary's advice is written from a parent's perspective and that could be very helpful to you.

\section{I disagree with 5 . Pop ups are great.}

And I also disagree with any of the other suggestions if the child is the one who is choosing. Now, parents don't have to read the books they don't like, but if the kid wants it, then I buy it or check it out. There are too many nonreader, alliterate people to play around with a child's motivation to read.

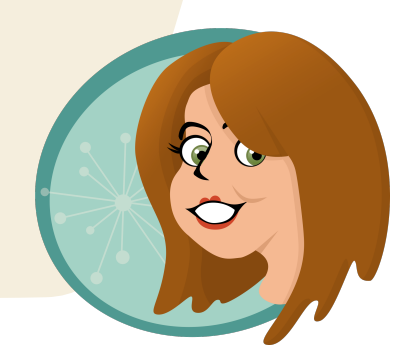

Yes, I'm a parent, but I'm a parent with a literacy obsession.

Bottom line: Preview the book and look for the elements you expect. You can preview books online and in the library or bookstore. It's called browsing. Visit sites such as Goodreads.com or Pinterest.com and search for books that match your criteria. 


\section{Know Your Financing Options: Library or Bookstore? Print or eBook?}

When you select a book, you have to know a lot about a lot of things. In addition to thinking about the mode of discourse (e.g., narration, information, description, or argumentation), you need to think about the genres because they blend and share rhetorical and visual purposes. You have to know the authors and illustrators-there are thousands from which to choose. And you have to phrase your response in the form of a question-what would the reader want? Given there is as much art as there is science in the process of book selection, you need to think about the long-term use of the book. Do you think the book will be read again and again? Will it become a favorite? Or, is the book for a short-term purpose such as a school report, a life event (starting school/college/a new job), or does the book feature a topic with a short life span (e.g., a biography of the latest boy band)?

\section{Ask Around}

Ultimately, if you want to select the right book for the right reader at the right time-ask the reader! They have opinions and they know good books. If they don't know "good," they know what they like; and therein lies the answer. 


\title{
An Opinionated Journey through Children's Literature
}

Through the Eyes and Mind of an Almost Teenager

\author{
By: Mary Schneider
}

Children have many different ideas of entertainment-from sports stories to science fiction to fantasy. The authors of books need to adjust the language of their writing to fit the interests of the audience.

\section{Part 1: Fiction Books}

Sports books. An obvious example would be a sporty book. The author might use slang or simpler words. Sports are not really labeled as a place to learn or fantasize. Children reading this type of book will most likely be reading it for the sport. They would choose a book that represents a sport of their liking. One where the focus is on the sport, not the players. The topic of almost every conversation would be about the sport. The point is, the audience of sports books are in it to read about the sport, and maybe a basic heartwarming story about a disabled player or the underdog team in a town. They are not in it as much for the highly intelligent and complicated plot line. Sports books should be an easy read. Not a book for toddlers, but simple and straight forward.

Science fiction. Another example would be sci-fi books. Sci-fi books should have a plot line that makes sense, but have multiple branches. Almost like mini-plots. Sci-fi books should also contain a few facts that blend into the story and make logical sense. Not like a nonfiction book, but also not like a fantasy novel. Take the science fiction show Doctor Who for example. (If you are unfamiliar with this television series, then take Star Wars or Star Trek as another example.) Although it is not a novel, it is the perfect example of a would-be amazing sci-fi book. The main character is a Time-Lord, which is a species from a different planet and different Galaxy. It provokes the audience to think deeply. It provokes wonder, and that infamous question: What if? What if there really is a world out there filled with creatures like this? What if there was actually a war going on in a different galaxy? A war between some of the most powerful beings in the cosmos? What if a few of them walk among us, tricking us into believing that they are one of us? What if there is a place on Earth that acts as a substitute for the notorious area 51? No one knows, but there are many theories in the form of Science Fiction novels, because that is what they are about. Science fiction novels induce a sense of wonder and questioning. They pull the reader in and make them think deeply through a series of events connected to create a complicated yet enthralling plot. 
When writing a sci-fi book the author should be caught up on their facts. Science Fiction authors are more committed to logic than fiction authors, but they can still create brilliant imaginary plots that have some facts in them. Like in Doctor Who, they harness the stability and power of the space-time continuum and manipulate it by using highly advanced technology to do their bidding. This may seem like a form of magic to some, but this is really just highly advanced technology that was made possible by an advanced species. The authors must always be creative.

Fantasy. Then there is Fantasy. Fantasy does not have to be logical. Fantasy includes books and series such as Harry Potter, Twilight, and Percy Jackson, etc. These books pull the reader into a world filled with magic, mystery, excitement, and adventure. The characters are whimsical, mysterious, and interesting. These worlds can abandon reason almost completely. Fantasy books can range from something like the Hunger Games which could possibly happen in the future, and contains only technical and manual activities, supplies, and happenings, to a series such as Harry Potter, which could not happen, and is filled almost completely with magical doings. Fantasy books are kind of like Sci-fi books, because of the fact that they should be enthralling and slightly complicated. They are unlike sci-fi books because they do not really provoke many deep questions. They may provoke some, but not ones like the "What if" question. These books are more meant to entertain the reader, and to unleash their imagination. These books enable the reader to wander a world unknown. And connect with the characters and their adventures.

When writing fantasy books the author might use a large vocabulary, create an intricate plot, and intelligent characters. Multiple events create a chain reaction that makes the book. Fantasy books are not really meant for a level 1 reader, so the author would be able to fill the pages with intelligent language and intelligently interesting events. The author should fill the book with action and adventure, along with some mysterious and mystical events, because that is what keeps the reader interested. The more time spent building up for the event the more the world that the audience is in fades. By this I mean that the transitions between the heartwarming, action-packed, hysterical, suspenseful, and tragic scenes should be quick: just a page or two that lets the reader catch their breath and get filled in on the happenings. Not every event has to be the extreme of one or two emotions, though. There can still be calm points, but they still have to be interesting. One basic calm point would be the aftermath of an extremely suspenseful event, or an ordinary day or activity in the life of the main character. These happenings are not necessarily exciting, but it gives the reader some insight into what the main characters are really like. These moments are extremely necessary because if the entire book was one big climax, then the reader would become confused and lost. A book that is all one note, whether that note is suspenseful or boring, is never a good read. 
Audience. So, basically, when the author begins to write a book, they should determine their audience. This is an instruction coming all the way from elementary school, but this is a very important one indeed. The type of audience is not just a matter of age or gender, but of interests. If the author chooses to create a sporty novel, then the reader will most likely be a sporty person, or at least a person that enjoys watching sports. While they may enjoy reads from other genres, they chose the sports novel to read about sports, not to get engaged in some intricate plot. Science fiction novels would be for a person who enjoys science to some degree, and someone who is able to think critically. Fantasy is for the reader just looking to be entertained and get away for a while. There will always be the extremely intelligent and scientific lover of sports. Just because they are intelligent does not mean that they are always looking for an advanced piece of literature. The author is always writing for a specific person in a specific mood, whether they know this or not. Authors are taught from a young age to first determine their audience. To many, this means a specific kind of person, and they should always write like they are reading the book in the mind of that one specific reader. This, however, could be a fatal flaw to many novels. People reading sports novels are not always dumb jocks. Throwing some science, math, or another more advanced topic into the book is not a bad idea, just like adding a little bit of sports into a Fantasy book is a good idea. Take Quidditch as an example. J.K. Rowling added sports into her novels, and made it a big thing. This way someone who loves sports would get a little taste of sports within the Fantasy novel. It widens the range of audience members for the book.

Relatable action. Another thing that makes novels interesting to kids would be the author injecting something that they can relate to into the book. Maybe there is a bully that uses verbal insults or practical jokes to bring down the protagonist ("ahem" Draco), or the stress of finding a date or having to look pretty all of the time, exams, grades, competitions, friends, and etc. If the main character is an adult, then the author might make him or her out to be a person that either is trying to find a date, or has trouble with their girlfriend or wife, because there is not really much that a child has to relate to an adult. The more the main characters are similar to the reader, the deeper the felt connection is, and the deeper the connection is, the more the reader enjoys the book. 


\section{Part 2: Nonfiction}

Nonfiction books are often dreaded by children. For me, they are the last resorts as I mainly use them for reports and research projects. Nonfiction books are very necessary and very helpful when it comes to research projects, and I am sure that there are many people who read them for recreation, but basically every single average teenager or child I know would not read a nonfiction book for fun (except my sister). I hate to be the one to say this, but the sad truth is that nonfiction books are just not that fun to read.

I love her, but I totally disagree with Mary on this one. What you have here is a matter of opinion and preference-which is the whole point of this chapter. You have to match the right book to the right reader at the right time.

Mary's point is a good one and her experience is indicative of the instructional choices of her teachers. If nonfiction books are read as

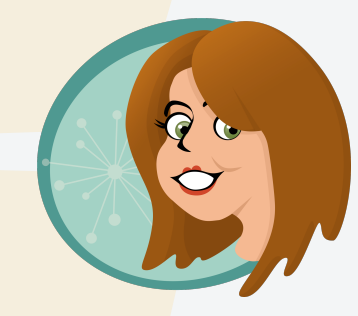
encyclopedias and children must hunt and peck for information in order to regurgitate it accurately, then they will not enjoy reading nonfiction. If, however, nonfiction books are used to explore a topic and if well-written nonfiction books are used to entice reading, then they can be engaging.

Animal books. However, some books are better than others. Most class reports now are about animals, technology, or history. The basic information needed for practically every project on animals nowadays would be: Where are they found? Are they endangered? How many are there on Earth (approximately)? What is the species' scientific name? What are the animal's basic predators and prey? What effect do humans have on this species? And finally, what are at least three interesting facts about this species? When writing a nonfiction book about a specific species, the author should put most of this information into the manuscript. If not, the book will most likely only frustrate the reader.

Biography questions. Some questions asked constantly about current technologies are: How does it work? When was it invented? Who invented it? How old were they? Do they have any other inventions? What was their childhood like? How did this invention affect humans? What are the pros and cons of this invention? How much does the human race depend on this invention? What effect does it have on the environment? Much of the information used to create reports on technologies is either about the inventor or the effect that the invention itself had on the environment and on the human race. Strangely enough, teachers do not ask for much information on the actual technology. 
Historical biographies and important questions. The questions constantly asked about people in history are: Who are they? What place did he or she have in society? What did the person do, have, or invent to become well known and remembered? In what era did he or she live? What year was the person born? What was the name of his or her spouse and children, if he or she had any? What year did this person die? Where did the person live? How did he or she get to be where they were when the person died? What are two or three important things that he or she did in his or her life? When did he or she do these things? And finally, once again, what are a few interesting facts about this person?

Many times, historic figures create a lot of headaches for students, because of all of the dates, accomplishments, and names of acquaintances and relatives that need to be included as well. The more packed with important information a biography is, the more helpful the book would be to a student.

History questions. Some questions commonly asked about events in history are: When did this event occur? What led to it? Why did this happen? Who participated in this event? What effect did it have on the future? What effect did it have on the people of that era? What are the pros and cons of this event occurring? Has this event had a lasting impression on the way things function? Why or Why not? Was this an international affair? There are normally fewer questions asked about events on reports because all that can really be asked is: How? When? Where? What? Why? And Who? The basics. There really isn't a way to embellish these questions, to add information. What you see is what you get. However, because there is not much more than the basics, the author must be sure to include everything. One piece of forgotten information will decrease the likeliness of a student reading the book and using the information.

If these questions are asked and answered, along with a few more extra facts, the nonfiction book will be very helpful to students, and it will be more likely to be bought by schools and libraries for their students.

Important features. When looking for nonfiction books for projects, students will most likely look for three main features. These features are pictures, level of detail, and citations. 
Pictures. On most research projects, the child will most likely need pictures. Therefore, the author should include multiple pictures. These pictures should be placed in the corners of the pages to leave the maximum amount of space for the actual information. The child will most likely also need a few random facts, so when writing a nonfiction book, the author would need to be sure to add some seemingly unnecessary information, because to the child reading the book, those few sentences could make or break their paper or presentation. However, one would need to balance this out. If the author fills the book with more random facts than basic and important information, then the reader will have to sort through the information to get what they need, which is not helpful.

Balancing length, detail, and reading level. Research projects are normally done in a short amount of time in a span of $1 \frac{1 / 2}{2}$ to 2 weeks. Because of this, the students would need a shorter book, but one that has all the necessary information and is written for their grade level. For students in the fifth, sixth, and even seventh grades, there is a shortage of books that can be used for most research projects. Many books are either too short, lacking in information, and written for a younger student; too long with too much information and written for an older student; just the right length but too much random information; and then there is the glorious book that has just the right number of facts, written for the middle school level, and only takes about fifteen minutes to read. The other types of books are necessary, but there is an excess of them, and a shortage of middle school level books. There is a very distinct balance of information to length to reading level that makes a nonfiction book interesting and worth reading. When writing this type of book, the author must always pay attention to this balance.

Citations. One problem that comes up constantly is the citations. Many times citations take up much of the time spent on creating the project, because the information is so hard to find sometimes. Some books have the information needed to create a citation separated between the cover, the back, and the front. If the author takes the extra few steps to either make sure that all of the basic information needed for citations, such as dates, publication companies, names, and addresses are all in the same place, or creates a citations page in the book, students will be that much more likely to pick up the book. 